\title{
HETEROGÉN ANYAGOK MEZOSZERKEZETÉNEK MECHANIKAI MODELLEZÉSE
}

\author{
GÁBOR EDIT* - BOJTÁR IMRE** \\ *PhD-hallgató. BME Tartószerkezetek Mechanikája Tanszék, 1111 Budapest, \\ Müegyetem rkp. 3. K mf. 63. Tel.: (+36-1) 463-1434. E-mail: gabor.edit@mail.bme.hu \\ **Dr. habil. egyetemi tanár. BME Tartószerkezetek Mechanikája Tanszék, 1111 Budapest, \\ Műegyetem rkp. 3. K mf. 63. Tel.: (+36-1) 463-1160. E-mail: ibojtar@mail.bme.hu
}

\begin{abstract}
A heterogén anyagok mezostruktúrájának vizsgálata mind a többszintű („multiscale”) modellezés, mind az anyagtechnológia szempontjából fontos feladat. A mikromechanika nyújtotta elméleti háttér bemutatása utána illusztráló példaként cikkünk megvizsgálja a heterogenitást tartalmazó anyagban keletkező feszültségmezőt az Eshelby-tenzoron alapuló analitikus, valamint végeselemes modellekből nyert numerikus eredmények segítségével. Az anyagmodellezés szintjeit összekapcsoló homogenizációs eljárások a cikk második felében kerülnek bemutatásra. Alkalmazásként a beton mezo- és makroszintü modellje közti átlagolási technikát ismertetjük. Összevetjük az analitikus, illetve a numerikus homogenizáció eredményeit, valamint felvázolunk néhány további lehetséges alkalmazási területet.
\end{abstract}

Kulcsszavak: heterogén anyag, mezoszint, Eshelby, Mori-Tanaka, homogenizáció, beton

\section{BEVEZETÉS}

Heterogén anyagok mechanikai vizsgálatát többféle megközelítési módon is elvégezhetjük (1. ábra), egészen az atomi szinttől a mikro- és mezoszinten át a makroszintig modellezhetőek az anyagok. Attól függően választhatjuk meg a modellezés szintjét, hogy a heterogén anyag mechanikai viselkedésének vizsgálata milyen pontosságú elemzést igényel. Az atomi szinttel a fizika, míg az anyagok mikroszerkezetével a kémia foglalkozik. Általánosságban elmondható, hogy a mérnöki számítások során az anyagok makroszerkezetét modellezzük. A mikro- és makroszintet köti össze az általunk is tárgyalt mezoszint, melynek vizsgálata már az anyagtudományokhoz köthető. Megjegyezzük, hogy az anyagtudományi szempontú vizsgálatok bizonyos esetekben az anyag mikroszintjén történnek. Példaként említjük, hogy a polimerek makromolekulái, a fémek polikristályai mérnöki szempontból elsősorban mikroszinten, a betonban, az aszfaltban, illetve a szemcsés anyagokban található heterogenitások - adalékanyagok, mikropórusok - mezoszinten vizsgálandók.

Többszintü (multiscale) modellezés esetén a vizsgált szerkezet anyagának numerikus modellezése különbözö anyagszerkezeti szinteken történik. A heterogén anyagszerkezet „pontos” figyelembevétele egy teljes szerkezet esetében indokolatlanul hosszú számítási időt - és szinte elérhetetlenül nagy kapacitású számítógépeket - 


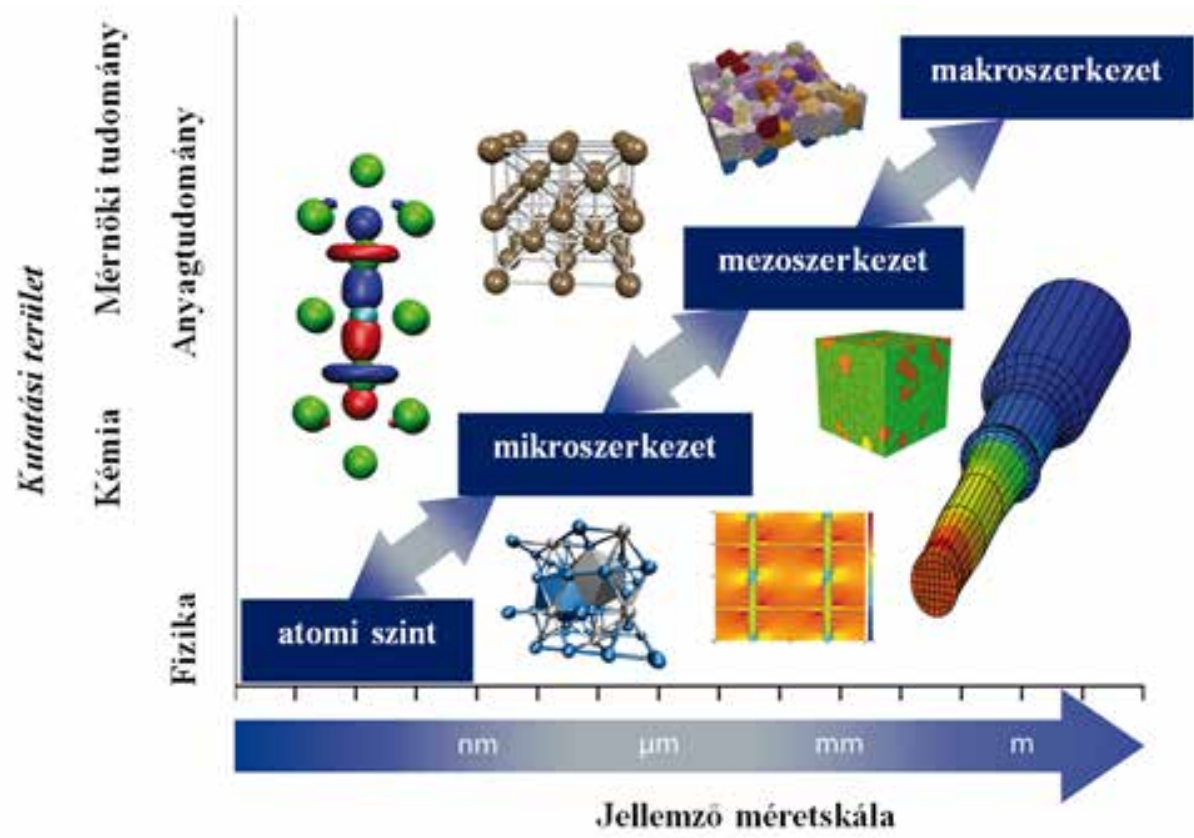

1. ábra. Az anyagmodellezés szintjei

igényelne, azonban a tönkremenetel szempontjából kritikus helyekre koncentrálva a makroszintü homogén anyagmodellt ezeken a helyeken mikro- vagy mezoszintü heterogén anyagmodellel kiváltva a szerkezet tényleges viselkedése sokkal pontosabban leírható.

A különböző modellezési szinteket egyfajta átlagolási technikával, a homogenizációs eljárásokkal kapcsoljuk össze. Egy „alacsonyabb” szinten ismert heterogenitás eloszlásának, az egyes részek alakjának és a heterogén anyag egyes fázisai fizikai paramétereinek alapján számíthatók az anyag effektív vagy átlagos anyagállandói egy „magasabb” szinten, ahol a különböző fázisokat már kontinuumként modellezzük.

A fentiek mellett az anyagtechnológiában új anyagok létrehozásánál, meglévőek fejlesztésénél is effektíven hasznosíthatóak a különböző szinteken történő modellezés eredményei. A költséges és időigényes laboratóriumi („trial-error”) módszerek mellett - és részben helyett - gyors és költségkímélő módszer lehet az anyagok numerikus modellezése egészen az atomi szinttől a makroszintig, ilyenkor minden egyes szint effektív anyagjellemzői az alacsonyabb szintek anyagjellemzőinek átlagolásából, homogenizációjából nyerhetőek.

Megjegyezzük azt is, hogy károsodott szerkezetek esetében a teherbírás megállapításakor roncsolásmentes vizsgálatok is kiválthatóak a belső szerkezetről kapott 
valamilyen képi felvétel (pl. CT, röntgen) feldolgozásával és az így nyert geometriai modellen végzett végeselemes analízisek eredményeinek felhasználásával (Lublóy et al. 2014).

Cikkünk először a mikro- és mezoszintủ modellezés mechanikai és matematikai hátterét mutatja be, arra koncentrálva, hogy ezen a szinten analitikusan hogyan vizsgálhatók a heterogén anyagok alakváltozás- és feszültségmezői (Gábor 2014). Ennek elemzésére az irodalomban fellelhető analitikus megoldásokat (Mura 1987) összevetjük végeselemes számítások eredményeivel. A cikk második felében az analitikus homogenizációs módszereket mutatjuk be, azokat az eljárásokat, amelyek segítségével egyszerü becslés adható egy heterogén közeg átlagos szilárdsági jellemzöire. Illusztráló példaként adott mennyiségü és minőségü adalékanyagból és cementböl álló beton esetében kiszámoljuk a beton átlagos rugalmassági modulusát és Poissontényezöjét mind analitikus, mind numerikus módon, majd összevetjük a különböző módszerek által kapott eredményeket.

\section{TÖRTÉNETI ÁTTEKINTÉS}

Az anyagok diszkrét szerkezetének „felfedezése” a Kr. e. 5. században élő Leukipposz nevéhez köthetö, gondolatmenetét később tanítványa, Démokritosz vitte tovább. Démokritosz szerint a világ végtelenül sok atomból épül fel ( a görög ,atomos" szó jelentése: oszthatatlan), melyek folyamatos mozgásban vannak az „ürességben".

Annak ellenére, hogy Démokritosz elmélete megfelelő kiindulási pontja lehetett volna a modern anyagtudományoknak, munkássága világi természete miatt elutasították, könyveit elégették, és csak más tudósok hivatkozásai alapján tanulmányozható modellje. A klasszikus görög filozófiában Platón elmélete vált széles körben elfogadottá, miszerint az anyagot alkotó részecskék négy fő elemből állnak: föld, tüz, víz és levegő, valamint az ötödik ,isteni” elemből, az univerzumot alkotó éterből (Platón valójában kvintesszenciának nevezte, az éter elnevezés Arisztotelész nevéhez köthetö).

Az anyagszerkezet diszkrét jellegére vonatkozó utalások a későbbi századokban is gyakran előfordultak. Az 1600-as években a német csillagász, Johannes Kepler foglalkozott a hópelyhek hatszög alakjával, mely tulajdonságot a hó belső szerkezetére vezette vissza, továbbá kiemelte, hogy a természetben rengeteg helyen előfordul hasonló szimmetria, gondoljunk csak a méhsejtre. A századvég angol tudósa, Robert Hooke már mikroszkóppal vizsgálta különböző anyagok szerkezetét. Megfigyelte, hogy az anyagok mikroszerkezete kis, gömbszerü részecskékből tevődik össze. Kortársa, Newton a következő megállapítást tette: a tovább nem bontható, meghatározott alakú, méretủ és tulajdonságú részecskék sokkal keményebbek, mint a belölük felépülö porózus anyagok. 
A tudomány egyéb területein születő felfedezések segítették a 19-20. század tudósait, hogy kísérletekkel megalapozott elméleteket, tételeket fogalmazzanak meg. 1808-ban fogalmazta meg az angol John Dalton atomelméletét, mely szerint minden kémiai elem egyedi jellemzőjü atomokból épül fel, amiket nem lehet megváltoztatni vagy felbontani kémiai folyamatok segítségével. A francia René-Just Haüy a kristályszerkezetek rendszertanát kutatta, és azt állította, hogy a kristályok poliéderes szerkezetűek. Ezeket a poliédereket a francia August Bravais osztályozta, egyben bevezetve az egységcella fogalmát.

A 20. század közepén megjelentek az első homogenizációs eljárások, módszereik az anyagok inhomogén természetének figyelembevételére irányultak a mechanikai számításokban. 1957-ben publikálta Eshelby az izotrop anyagba ágyazott ellipszoid alakú inhomogenitásról szóló cikkét, mely a mikromechanika nagy áttörésének számít a mai napig (Eshelby 1957). A 60-as évek kutatásai már a homogenizációs eljárások kifejlesztésére irányultak, többek közt Hill (Hill 1963, 1965), Hashin, Shtrikman (Hashin-Shtrikman 1961, 1963), Budiansky és Tsai foglalkoztak mélyrehatóan ezen technikákkal. Az 1970-80-as években továbbfejlesztették az analitikus megoldásokon alapuló homogenizációs eljárásokat (röviden: analitikus homogenizáció) (Willis 1977, 1981; Hashin 1988).

A jelenlegi kutatások az elméleti mikromechanika tételeit és a modern numerikus módszereket igyekszenek egyesíteni. A számítástechnika rohamos fejlődésének köszönhetően előtérbe kerültek a számítógépes fizika eljárásai, melyek általános fizikai problémák megoldását teszik lehetővé a legmodernebb numerikus technikák felhasználásának segítségével. A számítógépes homogenizáció (Geers et al. 2011) nélkül a manapság egyre szélesebb körben elterjedö többszintủ anyagmodellezés vagy a bevezetőben is említett számítógéppel segített anyagtervezés sem válna lehetségessé.

\section{A MEZOSZINTÜ MODELLEZÉS ELMÉLETI HÁTTERE}

\section{MATEMATIKAI ÉS MECHANIKAI HÁTTÉR (MuRA 1987)}

A mikromechanika matematikai eszköztárának alapvető elemei a Green-függvények, amelyek definíció szerint parciális differenciálegyenletek impulzív válaszfüggvényei. Az

$$
L u(x)=f(x)
$$

inhomogén parciális differenciálegyenlethez és

$$
B u(x)=0
$$


peremfeltételhez tartozó Green-függvény lineáris transzformációja maga a Diracdelta függvény:

$$
L G(x, s)=\delta(x-s)
$$

ahol $L=L(x)$ lineáris operátor, $B$ a peremfeltételeket megadó általános operátor, $G(x, s)$ az adott problémához tartozó Green-függvény, és $\delta(x-s)$ a Dirac-delta függvény. (3.3) konvolúciója egy - a feladatban adott $-f(s)$ függvénnyel:

$$
\int L G(x, s) f(s) \mathrm{d} s=\int \delta(x-s) f(s) \mathrm{d} s=f(x)=L u(x),
$$

amely során a Dirac-delta függvényt mint egységmagot alkalmazva visszanyerjük a (3.1) alakú eredeti problémát. Az $L$ operátor linearitása miatt az inhomogén parciális differenciálegyenlet megoldása kifejezhető a Green-függvény és az adott $f(s)$ függvény segítségével:

$$
u(x)=\int G(x, s) f(s) \mathrm{d} s
$$

A fenti kifejezés bizonyos esetekben csak közelítő megoldást ad, mert a (3.5) képletben szereplő szorzatintegrál gyakran csupán közelítő módszerekkel számítható.

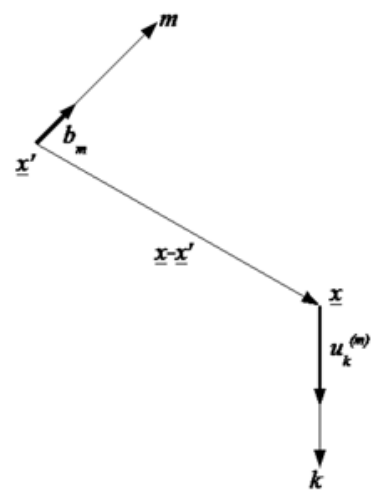

2. ábra. Elmozdulás egy pontszerủ erő hatására

A mechanikai problémák esetében sokszor inhomogén differenciálegyenletet tartalmazó peremérték-feladatok megoldásánál használjuk a Green-függvényeket. Példaként egy testre ható pontszerü erő hatására létrejövő elmozdulások számítását említjük. A problémához tartozó $G_{k m}$ Green-függvény megadja a háromdimenziós térben $\underline{x}^{\prime}$ helyen müködő $m$ irányú pontszerü erő hatására az $\underline{x}$ koordinátájú pont $k$ irányban létrejövő elmozdulását (2. ábra):

$$
u_{k}^{(m)}=G_{k m} .
$$

A kétváltozós Green-függvény, így az elmozdulásmezö is transzláció-invariáns, vagyis független a vizsgált pont, illetve a pontszerü erő konkrét helyétől, csupán a két pont helyvektorainak különbségvektorától $\left(\underline{x}-\underline{x^{\prime}}\right)$

függ: $G_{k m}\left(\underline{x}-\underline{x}^{\prime}\right)=G_{k m}\left(\underline{x}-\underline{x}^{\prime}\right)$.

Izotrop anyagok negyedrendủ anyagi merevségi mátrixa felírható a $\lambda, \mu$ Laméállandók és a $\delta_{i j}$ Kronecker-delta függvény segítségével:

$$
C_{i j k l}=\lambda \delta_{i j} \delta_{k l}+\mu\left(\delta_{i k} \delta_{j l}+\delta_{i l} \delta_{j k}\right),
$$


mely alapján levezethető a fenti problémához tartozó Green-függvény explicit alakja izotrop anyagok esetére:

$$
G_{k m}\left(\underline{x}-\underline{x}^{\prime}\right)=\frac{1}{8 \pi \mu}\left(\delta_{k m} \nabla^{2}-\frac{\lambda+\mu}{\lambda+2 \mu} \frac{\partial^{2}}{\partial x_{k} \partial x_{m}}\right)\left|\underline{x}-\underline{x}^{\prime}\right| .
$$

A heterogén anyagban keletkező $\varepsilon_{i j}$ alakváltozás-mező felbontható egy, a külső terhek hatására létrejövő $e_{i j}$ alakváltozásra, valamint egy $\varepsilon_{i j}^{*}$ sajátalakváltozás-mezöre, ami például hömérséklet-változás, fázistranszformáció vagy egyéb, az anyag belső szerkezetében megjelenő változások hatására alakul ki:

$$
\varepsilon_{i j}=e_{i j}+\varepsilon^{*}{ }_{i j}=\frac{1}{2}\left(u_{i, j}+u_{j, i}\right) .
$$

$\mathrm{Az} \varepsilon_{i j}^{*}$ sajátalak-változások hatására az anyagban fellépő $\sigma_{i j}^{*}$ feszültségmezőt sajátfeszültségeknek hívjuk, melyek jellemzője, hogy külső terhek jelenléte nélkül is egyensúlyi rendszert alkotnak.

A heterogén anyagon belül megkülönböztetünk zárványokat, inhomogenitásokat és inhomogén zárványokat (3. ábra). Zárványról beszélhetünk abban az esetben, ha egy $D$ homogén anyag egy $\Omega$ véges tartományán belül adott egy $\varepsilon_{i j}^{*} \neq 0$ sajátalakváltozás-mező. Egy anyagban található $\Omega$ inhomogenitás az őt körülvevő ágyazóanyagtól eltérő anyagi tulajdonságokkal rendelkezik: $C_{i j k l}^{*} \neq C_{i j k l}$, ahol $C_{i j k l}^{*}$ és $C_{i j k l}$ az inhomogenitás, illetve az ágyazóanyag negyedrendủ anyagi merevségi tenzora. Abban az esetben, ha egy $\Omega$ véges méretű tartományon belül létezik $\varepsilon_{i j}^{*} \neq 0$ sajátalakváltozás-mező, valamint $\Omega$ tartományra érvényesek az inhomogenitásnál bevezetett tulajdonságok is $\left(C_{i j k l}^{*} \neq C_{i j k l}\right)$, akkor inhomogén zárványról beszélünk $(\mathrm{Qu}-\mathrm{Cherkaoui}$ 2006).

Eshelby a következő problémát vizsgálta (Eshelby 1957): tekintsünk egy végtelen kiterjedésü homogén anyagot, mely egyetlen ellipszoid alakú, konstans sajátalak-változással $\left(\varepsilon_{i j}^{*}(\underline{x})=\varepsilon_{i j}^{*}\right)$ rendelkezö zárványt tartalmaz. Az ellipszoid $a_{1}, a_{2}, a_{3}$ féltengelyei rendre az $x_{1}, x_{2}, x_{3}$ koordinátatengelyekkel párhuzamosak (4. ábra). A vizsgált végtelen kiterjedésủ anyag peremein elöírt feszültségek müködnek.

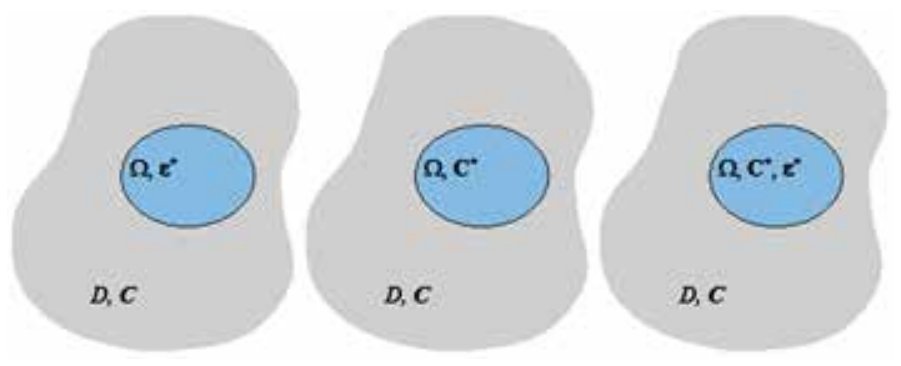

3. ábra. Zárvány $(a)$, inhomogenitás $(b)$ és inhomogén zárvány $(c)$ 


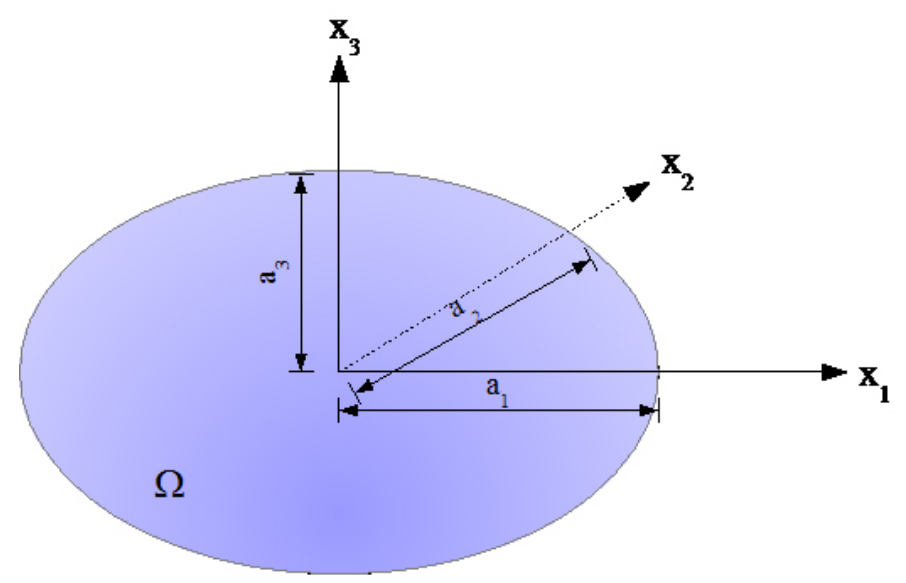

4. ábra. Ellipszoid alakú zárvány

Eshelby a végtelen kiterjedésủ anyagokra kidolgozott $G_{i j}^{\infty}\left(\underline{x}, \underline{x}^{\prime}\right)$ Green-függvény segítségével állította elő azt a $P_{i j k l}^{\Omega}(\underline{x})$ negyedrendủ tenzort, mely kapcsolatot teremt a heterogén anyag $\varepsilon_{i j}(\underline{x})$ teljes alakváltozása és a zárvány $\varepsilon_{i j}^{*}(\underline{x})$ sajátalak-változása között:

$$
P_{i j k l}^{\Omega}(\underline{x})=\int_{\Omega} \frac{1}{4}\left(\frac{\partial^{2} G_{k i}^{\infty}\left(\underline{x}, \underline{x}^{\prime}\right)}{\partial x_{j} \partial y_{l}}+\frac{\partial^{2} G_{k j}^{\infty}\left(\underline{x}, \underline{x}^{\prime}\right)}{\partial x_{i} \partial y_{l}}+\frac{\partial^{2} G_{l i}^{\infty}\left(\underline{x}, \underline{x}^{\prime}\right)}{\partial x_{j} \partial y_{k}}+\frac{\partial^{2} G_{l j}^{\infty}\left(\underline{x}, \underline{x}^{\prime}\right)}{\partial x_{i} \partial y_{k}}\right) d V\left(\underline{x}^{\prime}\right) .
$$

$\operatorname{Az} \varepsilon_{i j}(\underline{x})$ teljes alakváltozás-mező és a hozzá tartozó $\sigma_{i j}(\underline{x})$ feszültségmezö:

$$
\begin{gathered}
\varepsilon_{i j}(\underline{x})=C_{k l m n} \varepsilon_{m n}^{*} P_{i j k l}^{\Omega}(\underline{x}), \\
\sigma_{i j}(\underline{x})=C_{i j k l}\left(C_{p q m n} \varepsilon_{m n}^{*} P_{k l p q}^{\Omega}(\underline{x})-\varepsilon_{k l}^{*}\right) .
\end{gathered}
$$

Mivel a Green-függvény parciális deriváltjait tartalmazó negyedrendủ $P_{i j k l}(\underline{x})$ tenzor kiszámítása általános esetben nehézkes, az elliptikus $I$-integrálok segítségével explicit kifejezéseket dolgoztak ki izotrop anyagok esetére (Mura 1987).

A fentiekre építve Eshelby bevezette továbbá a negyedrendü $S_{i j k l}(\underline{x})$ Eshelbytenzort:

$$
S_{i j k l}(\underline{x})=\mathrm{C}_{m n k l} P_{i j m n}^{\Omega}(\underline{x}),
$$

mely közvetlen kapcsolatot teremt a heterogén anyag $\varepsilon_{i j}(\underline{x})$ teljes alakváltozás-mezöje, valamint a zárvány $\varepsilon_{i j}^{*}$ sajátalak-változása között: 


$$
\varepsilon_{i j}(\underline{x})=\mathrm{S}_{i j k l}(\underline{x}) \varepsilon_{k l}^{*} .
$$

A heterogén anyag $\sigma_{i j}(\underline{x})$ feszültségmezője is kifejezhető az Eshelby-tenzor segítségével:

$$
\sigma_{i j}(\underline{x})=C_{i j k l}\left(S_{k l m n}(\underline{x}) \varepsilon_{m n}^{*}-\varepsilon_{k l}^{*}\right)=C_{i j k l}\left(S_{k l m n}(\underline{x})-I_{k l m n}\right) \varepsilon_{m n}^{*},
$$

ahol $I_{i j k l}$ a negyedrendű egységtenzort jelöli.

Eshelby megoldása alapján a Green-függvények parciális deriváltjait tartalmazó $P_{i j k l}^{\Omega}(\underline{x})$ tenzor $\underline{x} \in \Omega$ esetén konstans, melyböl következik, hogy az $S_{i j k l}(\underline{x})$ Eshelbytenzor is konstans a zárvány belső pontjaira nézve, tehát (3.14), valamint (3.15) alapján a zárvány belsejében az alakváltozások és feszültségek értéke állandó: $\varepsilon_{i j}(\underline{x})=\varepsilon_{i j}, \sigma_{i j}(\underline{x})=\sigma_{i j}, \underline{x} \in \Omega$.

Eshelby megoldása alapján nemcsak zárványok, de inhomogenitások és inhomogén zárványok is vizsgálhatóak. Az ún. „ekvivalens zárvány-módszer” lényege, hogy az inhomogenitást zárványként modellezzük úgy, hogy a fiktív zárvány $\sigma_{i j}^{*}(\underline{x})$ sajátalak-változása ugyanazt a $\sigma_{i j}(\underline{x})$ feszültségmezöt eredményezze, mint az eredeti inhomogenitás az elöírt $\sigma_{i j}^{0}(\underline{x}) \neq 0$ peremfeltételek mellett (5. ábra) (Mura 1987; Gábor 2014).

Ha a $C_{i j k l}$ anyagi merevségü anyag nem tartalmazna inhomogenitást, a keletkező $\sigma_{i j}(\underline{x})$ feszültségmező nagysága megegyezne a peremeken elöírt $\sigma_{i j}^{0}(\underline{x})$ feszültségek értékével. Az inhomogenitás jelenléte miatt azonban megváltozik a feszültségek értéke, így a heterogén anyag feszültségmezeje felbontható egy homogén anyagot jellemző $\sigma_{i j}^{0}(\underline{x})$ és egy perturbációs $\sigma_{i j}^{p}(\underline{x})$ részre:
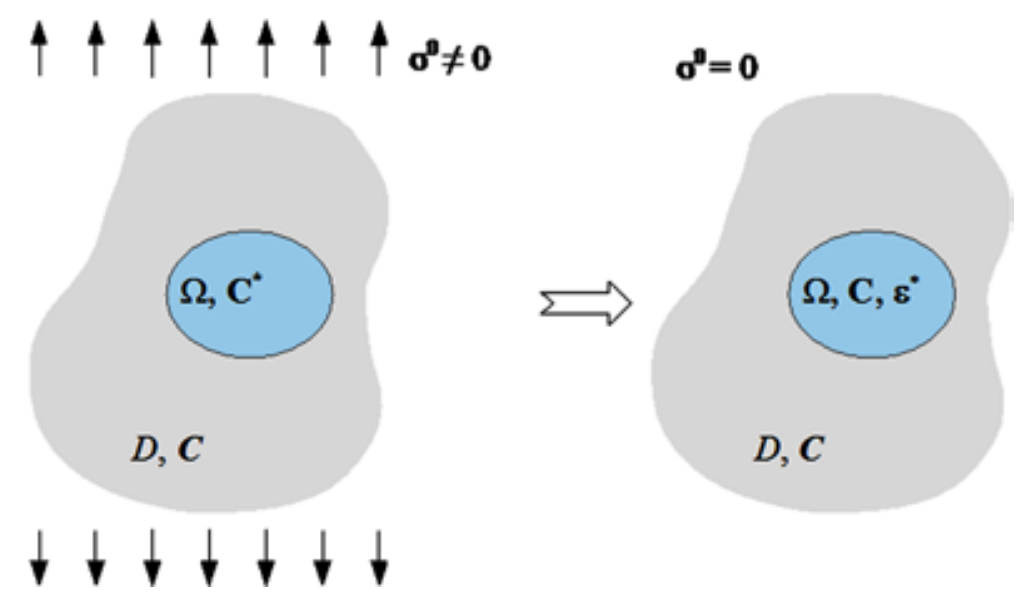

5. ábra. Inhomogenitás modellezése Eshelby megoldása alapján 


$$
\sigma_{i j}(\underline{x})=\sigma_{i j}^{0}(\underline{x})+\sigma_{i j}^{p}(\underline{x}) .
$$

Hasonlóan, a heterogén anyag $\varepsilon_{i j}(\underline{x})$ alakváltozás-mezeje is felbontható egy, a homogén anyagot jellemző $\varepsilon_{i j}^{0}(\underline{x})$ és egy perturbációs $\varepsilon_{i j}^{p}(\underline{x})$ részre:

$$
\varepsilon_{i j}(\underline{x})=\varepsilon_{i j}^{0}(\underline{x})+\varepsilon_{i j}^{p}(\underline{x}),
$$

ahol a homogén anyagra jellemző alakváltozás és az előírt feszültség kapcsolata:

$$
\sigma_{i j}^{0}=C_{i j k l} \varepsilon_{k l}^{0} .
$$

Lineárisan rugalmas anyag esetén a Hooke-törvényt felírva $\Omega$ heterogenitáson belül, és áttérve a Voigt-féle jelölésmódra, valamint ennek megfelelelően a negyedrendü anyagi merevségi tenzor helyett annak kétdimenziós mátrixát használva:

$$
\sigma_{i}=\sigma_{i}^{0}+\sigma_{i}^{p}=C_{i j}^{*}\left(\varepsilon_{j}^{0}+\varepsilon_{j}^{p}\right) .
$$

A heterogenitáson kívüli lineárisan rugalmas $D-\Omega$ tartományra felírva a Hooketörvényt:

$$
\sigma_{i}=\sigma_{i}^{0}+\sigma_{i}^{p}=C_{i j}\left(\varepsilon_{j}^{0}+\varepsilon_{j}^{p}\right) .
$$

Az ekvivalens zárvány-módszert alkalmazva tekintsük azt a fiktív $\Omega$ zárványt, mely anyagi merevségi mátrixa megegyezik az eredeti probléma $D-\Omega$ tartományának $C_{i j}$ anyagi merevségi mátrixával, és $\varepsilon_{i}^{*}$ konstans elöírt sajátalak-változása ugyanazt a $\sigma_{i j}(\underline{x})$ feszültségmezőt eredményezi a heterogén anyagban, mint a $C_{i j}^{*}$ anyagi merevségi mátrixszal rendelkező, de zérus elöírt sajátalakváltozás-mezejű inhomogenitás.

A Hooke-törvényt a helyettesítő zárványra felírva:

$$
\sigma_{i}=\sigma_{i}^{0}+\sigma_{i}^{p}=C_{i j}^{*}\left(\varepsilon_{j}^{0}+\varepsilon_{j}^{p}-\varepsilon_{j}^{*}\right),
$$

ahol $\sigma_{i}^{p}$ és $\varepsilon_{i}^{p}$ már a fiktív zárvány jelenléte miatt kialakuló perturbáció a feszültség-, illetve az alakváltozás-mezőben. Az Eshelby-tenzort $S_{i j}$ másodrendủ mátrixának segítségével kifejezhetô a zárvány okozta perturbáció az alakváltozásokban:

$$
\varepsilon_{i}^{p}=S_{i j} \varepsilon_{j}^{*},
$$

melyet behelyettesíthetünk a (3.21) egyenletbe:

$$
\sigma_{i}=\sigma_{i}^{0}+\sigma_{i}^{p}=C_{i j}^{*}\left(\varepsilon_{j}^{0}+S_{j k} \varepsilon_{k}^{*}-\varepsilon_{j}^{*}\right) .
$$

Felhasználva, hogy az inhomogenitás, valamint a fiktív zárvány okozta feszültségmezők azonosak ((3.19) és (3.23)): 


$$
C_{i j}^{*}\left(\varepsilon_{j}^{0}+S_{j k} \varepsilon_{k}^{*}-\varepsilon_{j}^{*}\right)=C_{i j}^{*}\left(\varepsilon_{j}^{0}+\varepsilon_{j}^{p}\right),
$$

valamint (3.22) újbóli figyelembevételével felírható

$$
C_{i j}^{*}\left(\varepsilon_{j}^{0}+S_{j k} \varepsilon_{k}^{*}-\varepsilon_{j}^{*}\right)=C_{i j}^{*}\left(\varepsilon_{j}^{0}+S_{j k} \varepsilon_{k}^{*}\right),
$$

melyből kifejezhető a szükséges fiktív sajátalakváltozás-mező értéke:

$$
\varepsilon_{i}^{*}=-\left(S_{i j}+\left(C_{i j}^{*}-C_{i j}\right)^{-1} C_{i j}\right)^{-1} \varepsilon_{j}^{0} .
$$

A heterogén anyagban elöírt feszültségek hatására keletkező feszültségmező (3.23) egyenletbe visszahelyettesítve számítható.

\section{HETEROGENITÁSOK KÖRNYEZETÉNEK MECHANIKAI VIZSGÁLATA}

Ebben a pontban Eshelby modelljét alkalmaztuk ellipszoid alakú inhomogenitások esetén, összevetve az általa kidolgozott analitikus megoldások és a végeselemes számítások eredményeit. Az analitikus számítások Eshelby „ekvivalens zárvány-módszer”-én alapszanak, a munka során a (Mura 1987)-ben található I-integrálokat alkalmaztuk.

Tekintsünk egy végtelen kiterjedésủ lineárisan rugalmas, homogén izotrop anyagba ágyazott lineárisan rugalmas, homogén izotrop anyagú ellipszoid alakú inhomogenitást. A heterogenitás $a_{1}, a_{2}, a_{3}\left(a_{1} \geq a_{2} \geq a_{3}\right)$ féltengelyei párhuzamosak az $x, y, z$ koordinátatengelyekkel. Különböző alakú és irányultságú inhomogenitásokat tekintve, elóállítottuk a heterogén anyagban egyirányú egységnyi elöírt nyomófeszültség hatására keletkező feszültségmezőt (6. ábra).

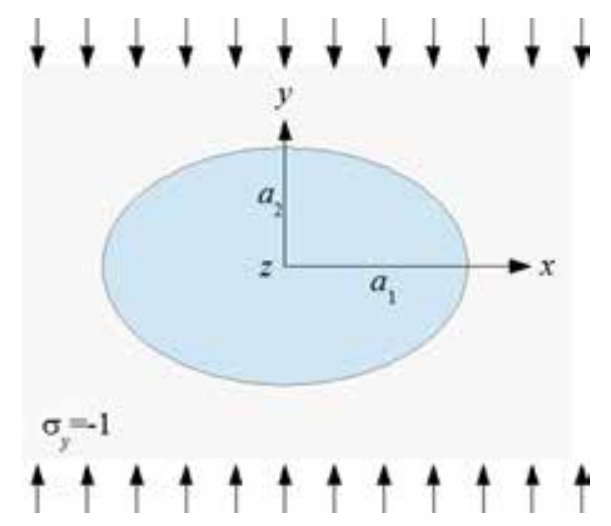

6. ábra. Heterogén anyag egységnyi nyomófeszültség alatt 


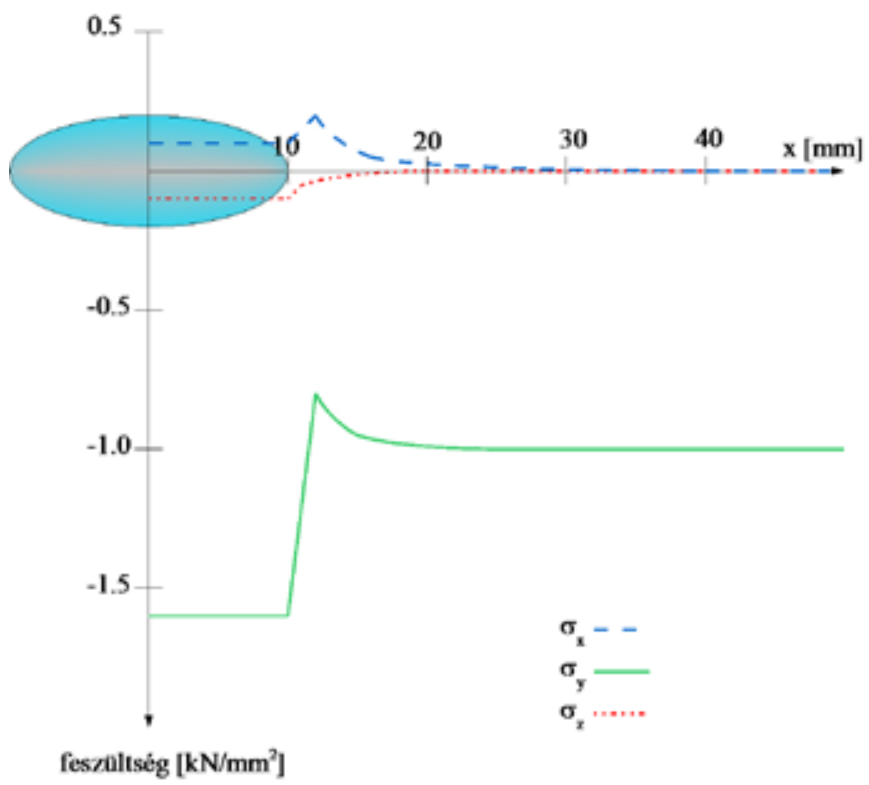

7. ábra. Az $y=0$ metszetben keletkező feszültségmező $a_{1} / a_{2}=2,5$ tengelyarányú forgásellipszoid esetén

Az alkalmazott anyagi paraméterek: $E_{i}=200 \mathrm{GPa}, \nu_{i}=0,3, E_{m}=20 \mathrm{GPa}$, $\nu_{m}=0,15$, ahol $E$ a rugalmassági modulust, $\nu$ a Poisson-tényezőt, $i$ index az inhomogenitást és $m$ index a mátrix (ágyazó-) anyagot jelöli. Az inhomogenitás mérete az $r=10 \mathrm{~mm}$ sugarú gömbtől az $a_{1} / a_{2}=1,25 ; 2,5 ; 10$ tengelyarányú forgásellipszoidokig változott $\left(a_{2}=a_{3}\right.$ feltétel mellett). A számítás során az Eshelby-tenzor elemeit a Chunfang Mengtől kapott Matlab ${ }^{\mathrm{TM}}$ algoritmus (Meng-Pollard 2014; MengHeltsley-Pollard 2012) segítségével számítottuk.

A 7. ábra az $y=0$ metszetben keletkező feszültségeket mutatja egy $a_{1} / a_{2}=2,5$ tengelyarányú forgásellipszoid esetén. A vízszintes tengely a homogenitás középpontjától mért $x$ távolságot, a függőleges tengely pedig a fötengelyt tartalmazó metszetben keletkező feszültségek nagyságát mutatja. Az ábrákon az inhomogenitás a valódi tengelyarányokkal van feltüntetve.

A fötengelyre merőleges $y$ irány $\sigma_{y}=-1 \mathrm{GPa}$ egységnyi nyomófeszültség a heterogenitás belsejében 1,7-szeresére nö, míg közvetlenül a heterogenitás előtt lecsökken (mindezt abszolút értékben értve). Az idegen anyag határán hirtelen ugrást figyelhetünk meg minden esetben a feszültségmezőben. A peremeken zérus értékủ $\sigma_{x}$ és $\sigma_{z}$ feszültségekben hasonló változás következik be: az ágyazóanyag-inhomogenitás határán egy hirtelen ugrást követően értékük nullától különböző konstans lesz, azonban amíg $\sigma_{z}$ a $\sigma_{y}$ feszültséghez hasonlóan csökken, addig $\sigma_{x}$ nő közvetlenül az 
inhomogenitás elött. Az ellipszoid fötengelyével párhuzamos irányú $\sigma_{x}$ feszültségek húzó-, míg az arra meröleges irányú $\sigma_{z}$ feszültségek nyomófeszültségek lesznek. Megfigyeltük továbbá, hogy a két különbözö - egyenként homogén - anyagban a feszültségek konstansok, ettől csak az anyaghatáron térnek el.

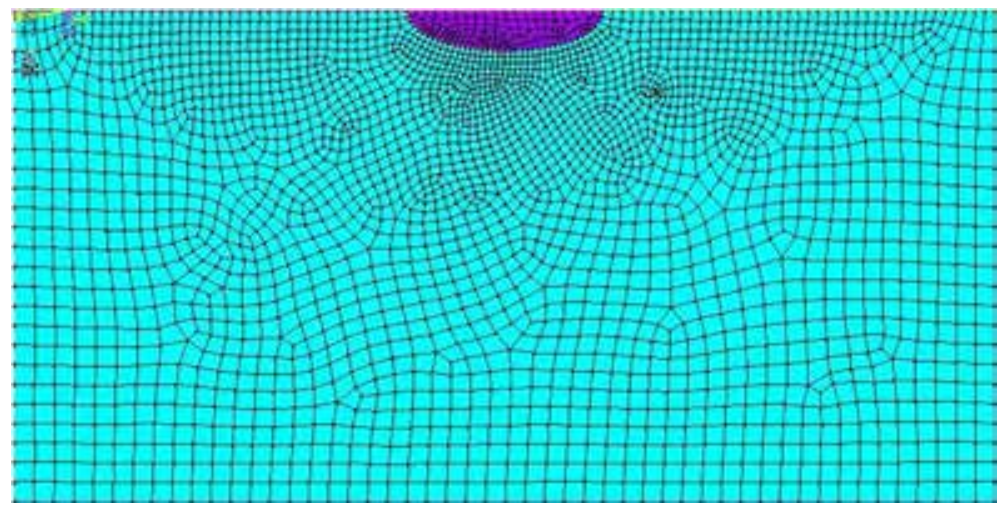

8. ábra. Végeselemes modell

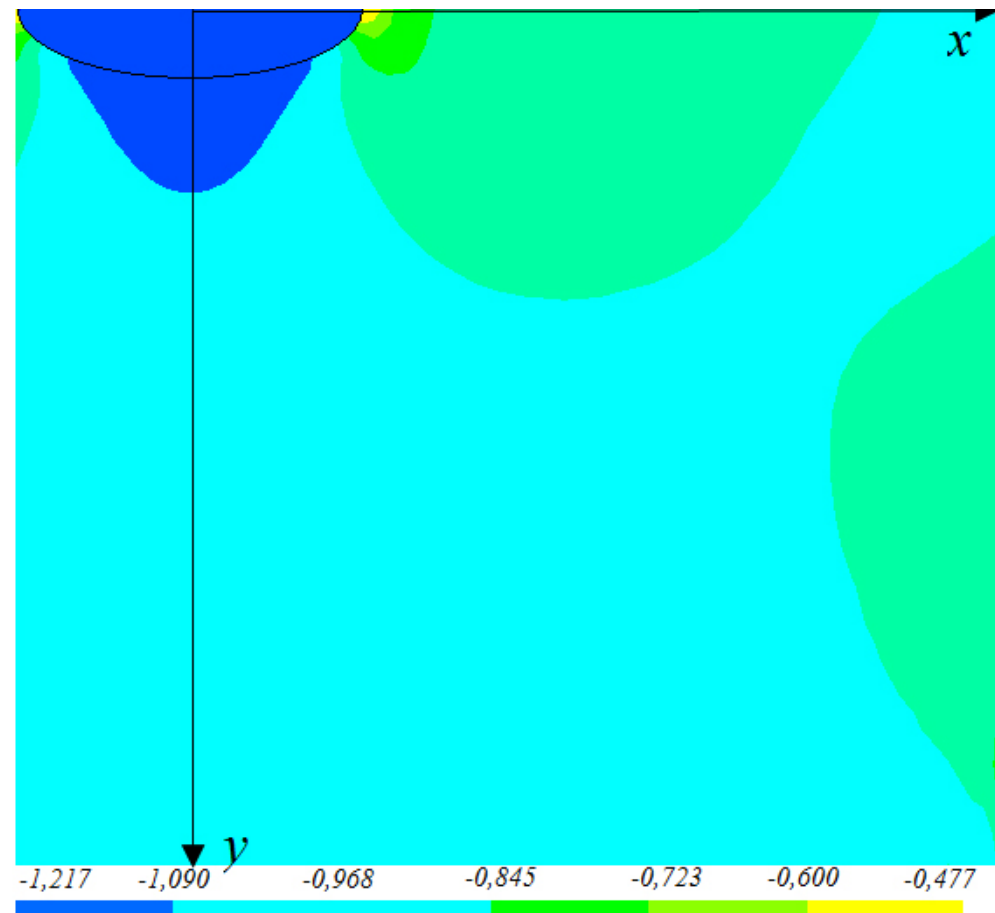

9. ábra. Feszültségmező a numerikus számítások alapján, $a_{1} / a_{2}=2,5$ tengelyarányú ellipszis esetén 
A 8. ábra az Ansys ${ }^{\mathrm{TM}}$ Mechanical APDL végeselemes szoftver segítségével készített numerikus modellt, a 9. ábra a vizsgálat eredményeit adja meg. A kétdimenziós numerikus modell esetén ugyanazokat az anyagi paramétereket, illetve fö- és kistengely arányokat használtuk, mint az analitikus számításoknál, azonban - síkbeli feszültségállapotot feltételezve - itt csupán az $x-y$ síkban vizsgáltuk a heterogén anyagot. Jól látható, hogy a 9. ábra bal szélén, az ellipszis közepétöl felfelé haladva ugyanazokat a feszültségértékeket tapasztaljuk, mint a 10. ábrán az analitikus képletek használata után. A heterogenitás belsejében egy abszolút értékében megnövekedett, de konstans nyomófeszültség tapasztalható, a két különböző anyag határán hirtelen csökkenést, majd fokozatos növekedést figyelhetünk meg a vízszintes irányú feszültségek abszolút értékében. A vizsgált tartomány szélén egyenlítődik ki a heterogenitás által megzavart feszültségmező, és tapasztaljuk az előírt egységnyi nyomófeszültség értékeket.

Az analitikus számítás nagy előnye, hogy gyors eredményeket biztosít, ugyanis nincs szükség a geometriai modell felépítésére, mint a numerikus futtatások eseté-

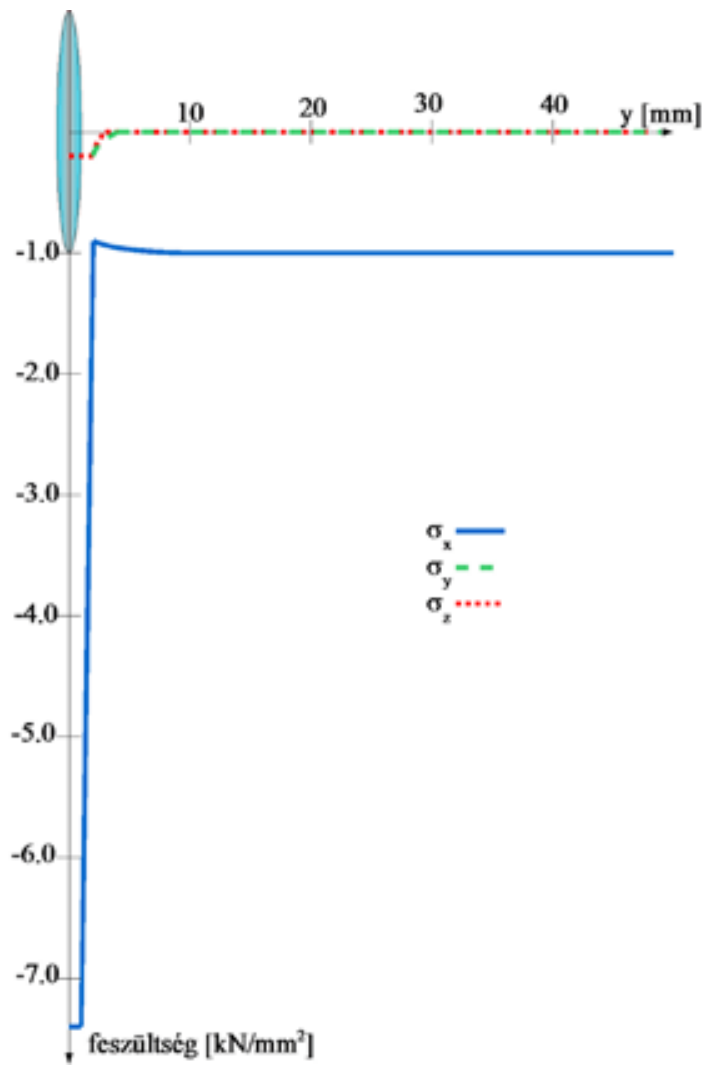

10. ábra. Feszültségmező $a_{1} / a_{2}=10$ tengelyarányú ellipszoid esetén 
ben. Az I-integrálok az Eshelby-tenzor számításánál történő alkalmazása miatt az analitikus eredmények is csak közelítő eredményeknek tekinthetőek, azonban összevethetőek a végeselemes modell által számított feszültségmezővel, és tapasztalataink azt mutatták, hogy a kétféle adat jól illeszkedik egymáshoz.

A 10. ábra az analitikus módon számított feszültségmezőt mutatja az $x=0$ metszetben egy elnyújtott, $a_{1} / a_{2}=10$ tengelyarányú forgásellipszoid esetén. Látható, hogy minél laposabb a heterogenitás a rá ható $\sigma_{x}=-1$ GPa feszültségekre merőleges $y$ irányban, annál nagyobb az inhomogenitás belsejében keletkező feszültség. A feszültségmező a heterogenitás belsejében konstans, az ágyazóanyagban pedig sokkal rövidebb távolságon egyenlítődik ki, mint az előírt feszültségre merőleges irányban kevésbé elnyújtott ellipszoid esetén.

\section{AZ ANALITIKUS HOMOGENIZÁCIÓS ELJÁRÁSOK}

A homogenizációs módszerek olyan átlagolási eljárások, melyek egy „alacsonyabb" szinten fázisonként ismert anyagi jellemzőjü és térfogatarányú heterogén anyag átlagos (más néven effektív) anyagjellemzőit számítják ki a „magasabb” szinten. Különböző fázisnak tekintjük az egymástól eltérő anyagi és/vagy geometriai tulajdonságokkal rendelkező, a heterogén anyagot alkotó - de külön-külön vizsgálva homogénnek tekintendő - anyagokat.

Ahogy a bevezetőben már említettük, minden anyag modellezhető az atomi szinttől egészen a makroszintig (11. ábra). A makroszinten homogén kontinuumnak tekintett anyag mezoszinten már heterogén anyagként modellezendő. A mezoszintü modell azonban fázisonként homogén anyagot feltételez. Ha az egyes fázisokat akár mikro-, akár atomi szinten tekintjük, az egyes fázisok újfent heterogén anyagként modellezendők.

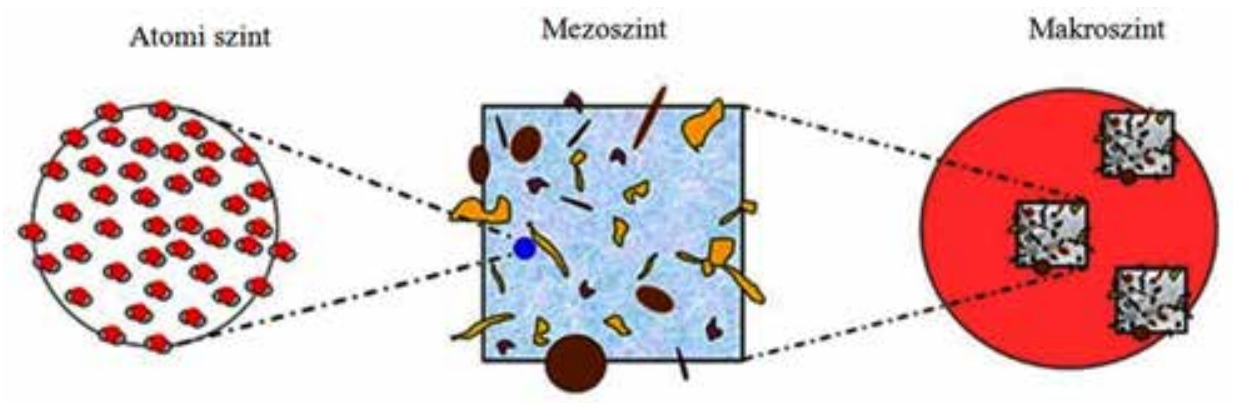

Atomokból felépaló heterogén fảzis
Heterogén térfogatelem

(fäzisonkẻnt homogén)
Homogén kontinuum

11. ábra. A homogenizáció szintjei 


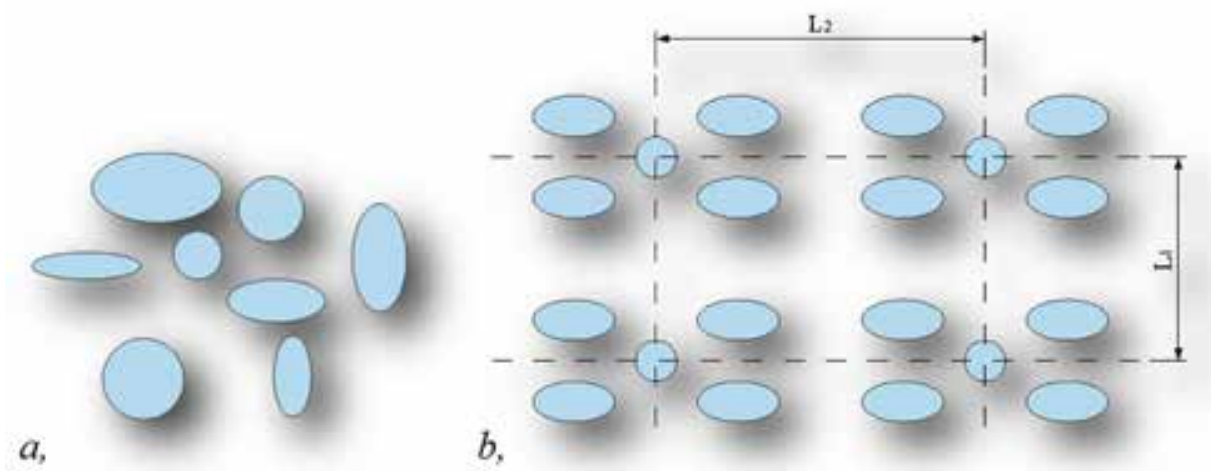

12. ábra. Nemperiodikus ( $a$ ) és periodikus $(b)$ eloszlású heterogenitások

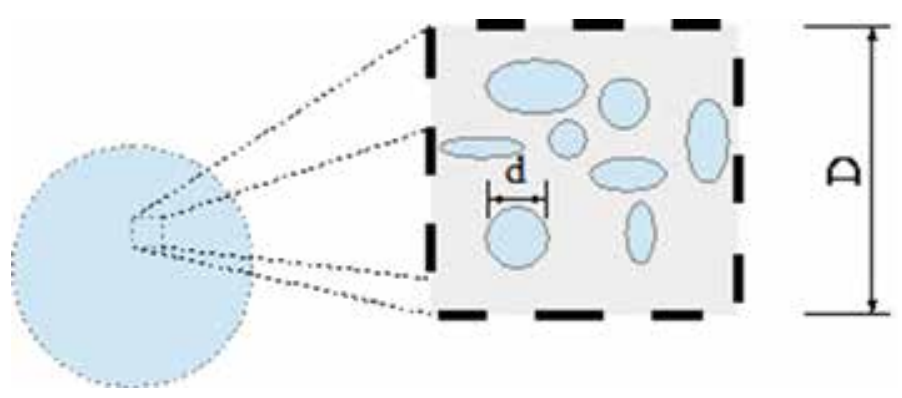

13. ábra. A reprezentatív térfogategység

A homogenizációs eljárások alapfeltevései a következők: az anyag nagyszámú heterogenitást tartalmaz, de statisztikusan homogénnek tekinthető. Utóbbi megjegyzés a heterogenitások egyenletes eloszlására utal. Az itt bemutatott homogenizációs módszerek csupán nemperiodikus eloszlású heterogenitásokkal foglalkoznak, azonban léteznek számítási módszerek a periodikus esetre is (12. ábra).

A homogenizáció során a makroszintű homogén anyagból egy ún. reprezentatív térfogategységet (Representative Volume Element, RVE) emelünk ki, melyre érvényes, hogy a $D$ makroszintü mérete nagyságrendekkel nagyobb a belső részeket jellemző $d$ mikroszintü méretnél: $d \ll D$. A $D$ élhosszúságú blokkot nevezzük reprezentatív térfogategységnek, míg $d$ a heterogenitások átlagos nagyságát jelöli (13. ábra).

Az analitikus homogenizáció során kétféle megközelítés létezik: az egyik a potenciális energia állandóértéküségének tétele felhasználása segítségével, variációs elveken alapul. Alkalmazásával egy alsó és egy felső korlátot kapunk az effektív anyagjellemzők értékére. A másik megközelítés az Eshelby-feladatból indul ki: a nagyszá- 


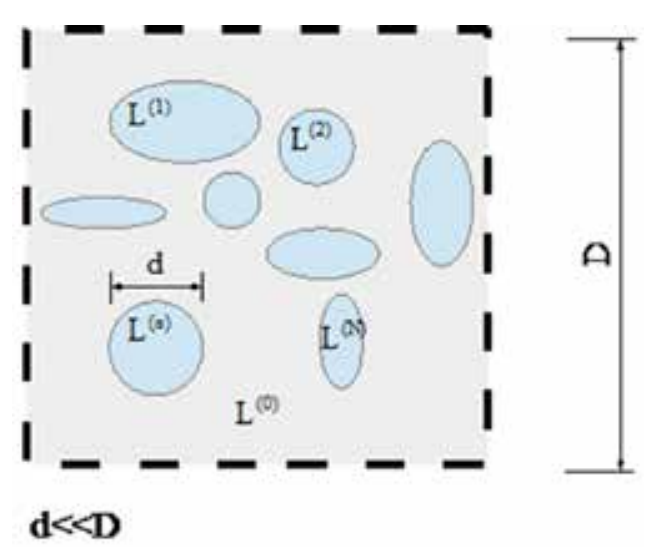

14. ábra. $N$ számú heterogenitást tartalmazó reprezentatív térfogatelem

mú heterogenitást egyetlen heterogenitásként modellezi, és a többi heterogenitás hatását az ágyazóanyag anyagállandóinak és előírt alakváltozásának változtatásával veszi figyelembe.

Tekintsünk példaként egy $N$ számú különböző inhomogenitást tartalmazó reprezentatív térfogatelemet. Az inhomogenitások akkor tekintendőek különböző fázisnak, ha vagy anyagi paramétereiket, vagy geometriájukat tekintve eltérnek a többi fázistól. Az ágyazó anyag legyen a „0" indexü fázis (14. ábra).

Jelölje az $r$-edik fázis anyagi merevségi tenzorát $L_{i j k l l}^{r}$, az anyagi hajlékonysági tenzorát $M_{i j k l}^{r}$, valamint a térfogatarányát $c^{r}$. A variációs elvek alapján levezetett eljárások az ún. Voigt-féle felső határt $\bar{L}_{i j k l}^{V}$ és a Reuss-féle alsó határt $\bar{L}_{i j k l}^{R}$ adják meg (Mura 1987; Gábor 2014):

$$
\begin{gathered}
\bar{L}_{i j k l}^{V}=\sum_{r=0}^{N} c^{r} L_{i j k l}^{r}, \\
\bar{L}_{i j k l}^{R}=\left(\sum_{r=0}^{N} c^{r} M_{i j k l}^{r}\right)^{-1} .
\end{gathered}
$$

Az Eshelby-feladaton alapuló megoldások közül az Eshelby- és a Mori-Tanaka-féle approximációt emeljük ki (Mori-Tanaka 1973; Mura 1987; Gábor 2014). Tekintsünk egy heterogén anyagot, melynek $S$ peremén elöírt feszültségek és/vagy elmozdulások müködnek:

$$
\begin{gathered}
\left.u_{i}\right|_{S_{u}}=\varepsilon_{i j}^{0} x_{j}, \\
\left.\sigma_{i j} n_{j}\right|_{S_{\sigma}}=\sigma_{i j}^{0} n_{j},
\end{gathered}
$$


ahol a konstans $\varepsilon_{i j}^{0}$ alakváltozás- és $\sigma_{i j}^{0}$ feszültségtenzorok (Voigt-féle jelölésmódot alkalmazva) közötti kapcsolat felírható az ágyazóanyag $L_{i j}^{0}$ anyagi merevségi mátrix segítségével:

$$
\sigma_{i}^{0}=L_{i j}^{0} \varepsilon_{j}^{0} .
$$

A heterogenitások jelenléte nélkül az anyagban keletkező feszültség- és alakváltozás-mezők konstansok lennének az anyag belsejében, azonban a heterogenitások megjelenése ebben a feszültségmezőben zavart kelt. Az Eshelby által vizsgált probléma - ahol az egyébként homogénnek tekintett anyag egyetlen inhomogenitást tartalmaz - segítségével modellezhető a fenti zavaró hatás. A perturbációt úgy vehetjük figyelembe, hogy az $r$-edik inhomogenitást egy olyan fiktív mátrixanyagba ágyazzuk, mely már előzetesen egy elöírt $\hat{\varepsilon}_{i}^{0}$ alakváltozással rendelkezik, továbbá a többi inhomogenitás hatását - melyek az Eshelby-feladaton alapuló modellünkben már nem szerepelnek - az ágyazóanyag anyagi paraméterein keresztül vesszük figyelembe, méghozzá a ágyazó anyag anyagi merevségi mátrixának egy fiktív $\hat{L}_{i j}^{0}$ értékre állításával (15. ábra).

A feladat újrafogalmazható az Eshelby-féle ekvivalens zárvány-módszernek megfelelően: egy ellipszoid alakú, $L_{i j}^{r}$ anyagi merevségggel rendelkező $\Omega_{r}$ inhomogenitás olyan $\hat{L}_{i j}^{0}$ anyagi merevséggel rendelkező mátrixanyagba van ágyazva, mely már az inhomogenitás megjelenése előtt előzetesen nemzérus $\hat{\varepsilon}_{i}^{0}$ alakváltozással rendelkezett. Az $\hat{L}_{i j}^{0}$ anyagi merevségi mátrix és az $\hat{\varepsilon}_{i}^{0}$ alakváltozás olyan értékekkel rendelkeznek, hogy a fent megfogalmazott egyetlen inhomogenitást tartalmazó anyagban keletkező feszültségek és alakváltozások azonosak legyenek az eredeti $r$ fázisból álló heterogén anyagban elöírt peremfeltételek mellett keletkező feszültség- és alakváltozás-mezővel. Az ekvivalens zárvány-módszer alapján felírható a módszer alapegyenlete:

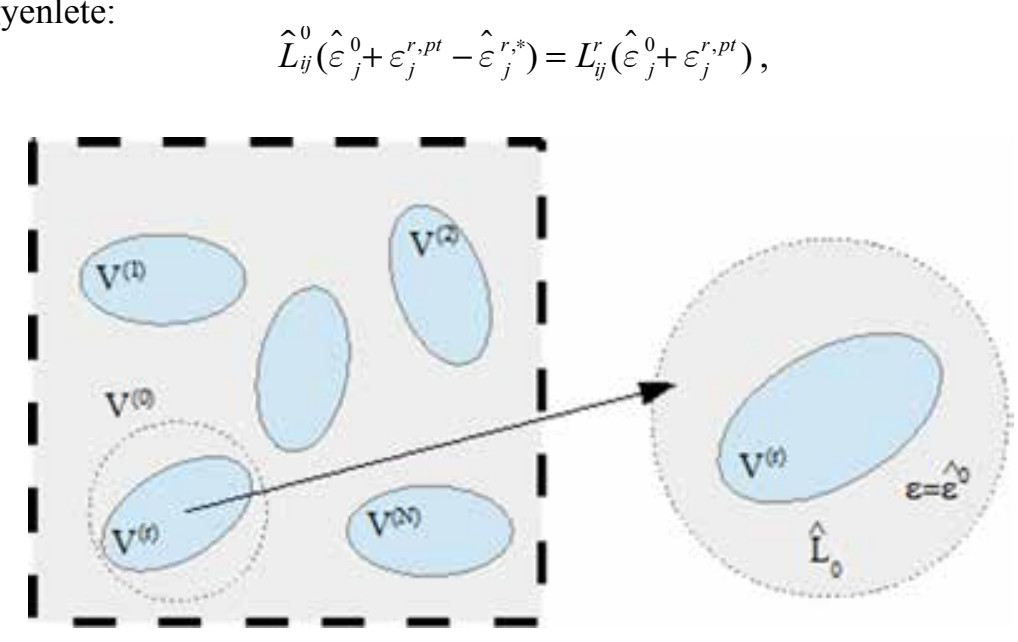

15. ábra. Az Eshelby-feladaton alapuló analitikus homogenizáció 
ahol $\varepsilon_{i}^{r^{* *}}$ az $\Omega_{r}$ fiktív zárvány fiktív sajátalak-változása és

$$
\varepsilon_{i}^{r, p t}=\hat{S}_{i j}^{r} \varepsilon_{j}^{r, *} .
$$

A fenti egyenletben $\hat{S}_{i j}^{r}$ a fiktív $\hat{L}_{i j}^{0}$ anyagi merevségi mátrix és az $\Omega_{r}$ inhomogenitás alakja alapján számított Eshelby-tenzor mátrixa. Az ekvivalens zárvány-módszer során alkalmazandó fiktív sajátalakváltozás-mező:

$$
\varepsilon_{i}^{r, *}=\left[\left(L_{i j}^{r}-\hat{L}_{i j}^{0}\right) \hat{S}_{j k}^{r}+\hat{L}_{i k}^{0}\right]^{-1}\left(L_{k l}^{r}-\hat{L}_{k l}^{0}\right) \hat{\varepsilon}_{l}^{0} .
$$

Látható, hogy az eredmények a fiktív $\hat{L}_{i j}^{0}$ és $\hat{\varepsilon}_{i}^{0}$ paraméterekhez rendelt értékektől függnek.

Ha az inhomogenitások az anyagban egymástól viszonylag távol helyezkednek el, az Eshelby-féle homogenizáció alkalmazható: ekkor nem vesszük figyelembe az $r$-edik inhomogenitásra a többi inhomogenitás által gyakorolt hatást, a fiktív anyagi merevség megegyezik az ágyazóanyag tényleges merevségével, illetve a fiktív alakváltozás az előírt alakváltozással:

$$
\begin{aligned}
& \hat{L}_{i j}^{0}=L_{i j}^{0}, \\
& \hat{\varepsilon}_{i}^{0}=\varepsilon_{i}^{0},
\end{aligned}
$$

így a fiktív Eshelby-tenzor az ágyazóanyag tényleges anyagi paraméterei, illetve az $\Omega_{r}$ inhomogenitás geometriája alapján számítandó:

$$
\hat{S}_{i j}^{r}=S_{i j}^{r} \text {. }
$$

Az Eshelby-féle becslés a heterogén anyag átlagos anyagi merevségi mátrixának értékére:

$$
\bar{L}_{i j}=L_{i j}^{0}+\sum_{r=1}^{N} c^{r}\left(L_{i k}^{r}-L_{i k}^{0}\right)\left[I_{k j}+S_{k l}^{r} M_{l m}^{0}\left(L_{m j}^{r}-L_{m j}^{0}\right)\right]^{-1},
$$

ahol $I_{i j}$ az egységmátrix, $M_{i j}^{0}$ az ágyazóanyag anyagi hajlékonysági mátrixa.

A Mori-Tanaka-közelítés az ágyazóanyagban olyan előzetes elöírt alakváltozás-mezőt feltételez, mely az eredeti heterogén anyag ágyazóanyagában keletkező alakváltozás-mezőt átlagolja, tehát figyelembe veszi a többi inhomogenitás jelenlétét is. A fiktív anyagi merevségi mátrix és Eshelby-tenzor számítása nem különbözik az Eshelby-féle becslés során alkalmazott értékektől:

$$
\hat{L}_{i j}^{0}=L_{i j}^{0} \text {, }
$$




$$
\begin{gathered}
\hat{\varepsilon}_{i}^{0}=\bar{\varepsilon}_{i}^{0}=\frac{1}{\Omega_{0}} \int_{\Omega_{0}} \varepsilon_{i} \mathrm{~d} V, \\
\hat{S}_{i j}^{r}=S_{i j}^{r} .
\end{gathered}
$$

A Mori-Tanaka-féle becslés a heterogén anyag átlagos anyagi merevségi mátrixának értékére:

$$
\bar{L}_{i j}=\sum_{r=0}^{N} c^{r} L_{i k}^{r} T_{k l}^{r}\left(\sum_{r=0}^{N} c^{r} T_{l j}^{r}\right)^{-1},
$$

ahol

$$
T_{i j}^{r}=\left[I_{i j}+S_{i k}^{r} M_{k m}^{0}\left(L_{m j}^{r}-L_{m j}^{0}\right)\right]^{-1} .
$$

A Mori-Tanaka-módszer a fiktív alakváltozás értékén keresztül figyelembe veszi a többi inhomogenitás hatását is, így pontosabb közelítést ad a heterogén anagy átlagos anyagjellemzőire, mint az Eshelby-féle becslés.

\section{A BETON ÁTLAGOS SZILÁRDSÁGI JELLEMZÖINEK SZÁMÍTÁSA HOMOGENIZÁCIÓS MÓDSZEREK SEGÍTSÉGÉVEL}

Az átlagos anyagi merevségi tenzorok kiszámítása segítségével meghatározható például egy fiktív betonkeverék átlagos (makroszintü) rugalmassági modulusa és Poisson-tényezöje az egyes fázisok anyagi paraméterei, térfogataránya és alakja alapján. A beton esetében többféle heterogenitást is figyelembe vehetünk: az ágyazó anyag legyen például a cementhabarcs, az egyes fázisok pedig az adalékanyag, valamint a légpórusok. Ha csak az adalékanyagot és a cementkövet vesszük figyelembe, kétfázisú, ha a légpórusokat is, háromfázisú modellről beszélhetünk. Négyfázisú modellt is alkothatunk például acélszál-erösítésü betonok esetén, az egyes szálakat rendkívül nagy fö- és kistengely arányú elnyújtott forgásellipszoidként modellezve.

Paraméteres vizsgálatokat folytattunk az egyes fázisok térfogatarányát, rugalmassági modulusát, valamint az adalékanyag méretét és alakját változtatva, és minden esetben meghatároztuk a beton átlagos rugalmassági modulusát és Poisson-tényezőjét a Voigt-féle felsö, a Reuss-féle alsó határ és az Eshelby-, illetve a MoriTanaka-féle becslés segítségével.

Az egyes fázisokat homogén izotrop anyagnak feltételeztük, és a cementet „,0”, az adalékanyagot „1”, a légpórust „2”, az acélszálat „3” indexszel jelöltük. A légpórus esetén a szingularitások elkerülése végett nullától különböző, nagyon kis értékeket vettünk fel a rugalmassági modulus és a Poisson-tényező megadásánál. 
A homogenizáció során a teljes anyagi merevségi mátrixra szükség van, mely a rugalmassági modulus és a Poisson-tényező segítségével kifejezve izotrop anyagok esetén:

$$
L_{i j}=\frac{E}{(1+\nu)(1-2 \nu)}\left[\begin{array}{cccccc}
1-\nu & \nu & \nu & 0 & 0 & 0 \\
\nu & 1-\nu & \nu & 0 & 0 & 0 \\
\nu & \nu & 1-\nu & 0 & 0 & 0 \\
0 & 0 & 0 & 1-2 \nu & 0 & 0 \\
0 & 0 & 0 & 0 & 1-2 \nu & 0 \\
0 & 0 & 0 & 0 & 0 & 1-2 \nu
\end{array}\right] .
$$

Az izotrop anyag átlagos rugalmassági modulusának és átlagos Poisson-tényezőjének számítása pedig épp ellenkezőleg, az átlagos anyagi merevségi mátrix $\bar{L}_{i j}$ elemeiből történik:

$$
\begin{gathered}
\bar{E}=\bar{L}_{11}-\frac{2 \bar{L}_{12}^{2}}{\bar{L}_{11}+\bar{L}_{12}}, \\
\bar{\nu}=\frac{\bar{L}_{12}}{\bar{L}_{11}+\bar{L}_{12}} .
\end{gathered}
$$

A cement rugalmassági modulusának változtatásával megfigyelhetjük a cement rugalmassági modulusának hatását a beton rugalmassági modulusára. Az ellipszoid alakú adalékanyag-szemcse féltengely-hosszai:

$a_{1}=10 \mathrm{~mm} ; a_{2}=9,9 \mathrm{~mm} ; a_{3}=9,8 \mathrm{~mm}$.

A cement és az adalékanyag térfogataránya, rugalmassági modulusa és Poissontényezője:

$c_{0}=0,4 ; c_{1}=0,6$;

$E_{0}=20 \div 35 \mathrm{GPa} ; E_{1}=30 \mathrm{GPa}$;

$\nu_{0}=0,15 ; \nu_{1}=0,20$.

Homogén anyag esetén $E_{0}=E_{1}=30 \mathrm{GPa}$ a kétfázisú modell egyes alkotóinak a rugalmassági modulusa, így az átlagos rugalmassági modulusnak ugyanekkora $30 \mathrm{GPa}$ nagyságú értékkel kell bírnia. Látható, hogy az eredmények a kerekítésekből származó hibákkal bírnak csupán (1. táblázat). Megfigyeltük, hogy minél nagyobb az eltérés az egyes fázisok paraméterei között, annál nagyobb különbségek jelentkeznek a különböző módszerek által kapott eredményekben. 
1. táblázat. A cement rugalmassági modulusának hatása a heterogén anyag átlagos rugalmassági modulusának értékére

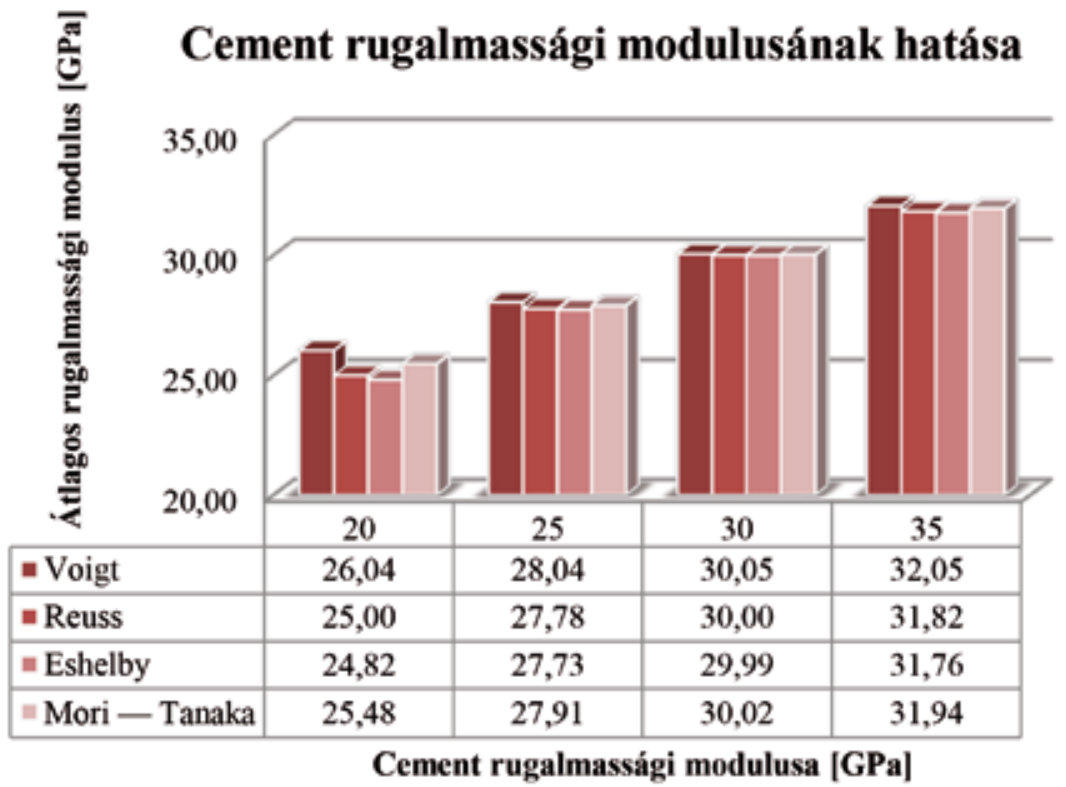

2. táblázat. Az inhomogenitás rugalmassági modulusának hatása a heterogén anyag átlagos rugalmassági modulusának értékére

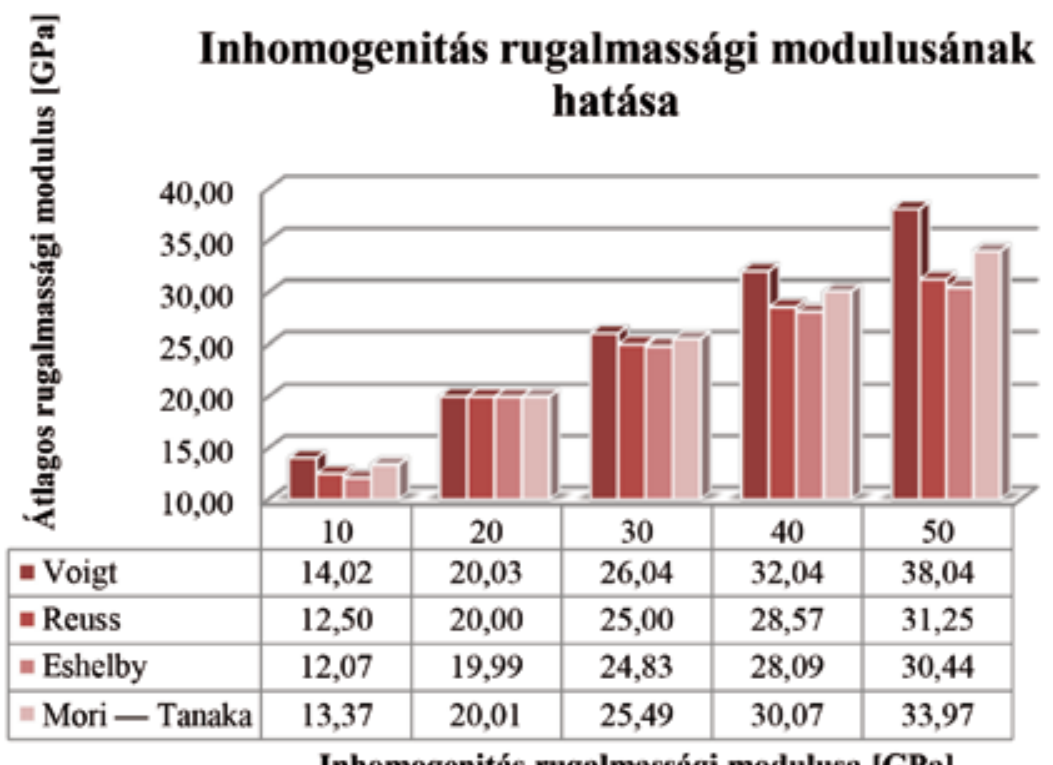

Inhomogenitás rugalmassági modulusa [GPa] 
Az inhomogenitás rugalmassági modulusának hatását vizsgálva csupán a rugalmassági modulusok értékeit változtattuk az előző vizsgálathoz képest:

$E_{0}=20 \mathrm{GPa} ; E_{1}=10 \div 50 \mathrm{GPa}$.

A kapott eredményeket diagramokon ábrázolva észrevehető, hogy az adalékanyag anyagi paraméterei nagyobb mértékben befolyásolják az elkészült beton viselkedését, mint a cementé, hiszen nagyobb térfogatarányban vannak jelen a betonban, így jobb minőségủ adalékanyag alkalmazásával nagyobb mértékben javíthatunk az elkészült beton minőségén, mintha az alkalmazott cement minőségét növelnénk (2. táblázat).

Az adalékanyag alakját forgásellipszoidként modelleztük, ahol két tengely hossza mindig megegyezik, és a harmadik hosszát változtattuk. Attól függően, hogy a harmadik tengely a mellék- vagy a főtengely, beszélhetünk lencseszferoidról $\left(a_{1}=a_{2}>a_{3}\right)$ vagy orsószferoidról $\left(a_{1}>a_{2}=a_{3}\right)$ (16. ábra).

Minél nagyobb a fö- és melléktengely arányszám, annál torzultabb ellipszoidot kapunk. A kellően nagy arány elérésekor lencseszferoid segítségével érme alakú inhomogenitást, orsószferoid segítségével pedig tủ alakú inhomogenitást modellezhetünk (17. ábra).
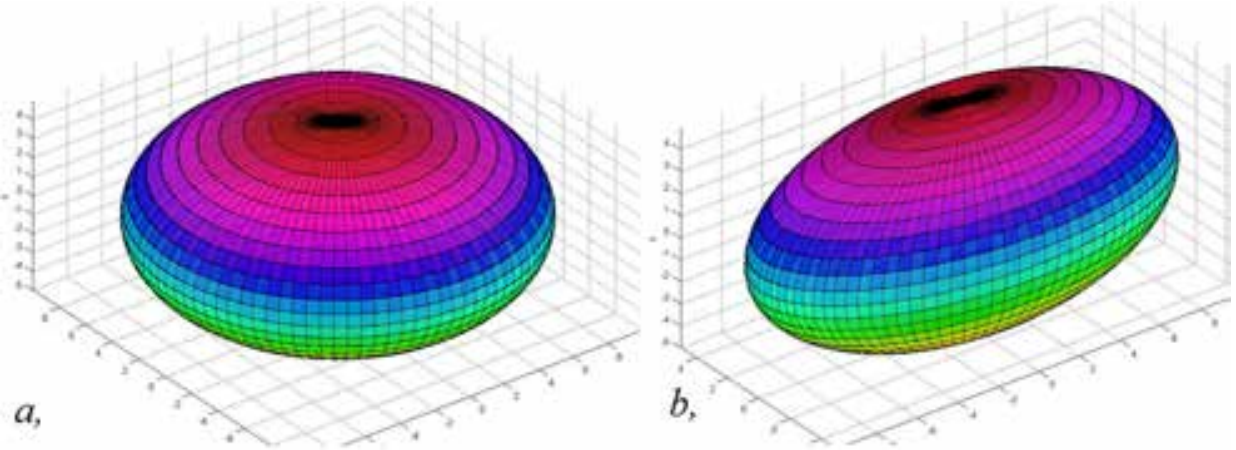

16. ábra. Lencse- (a) és orsószferoid $(b)$
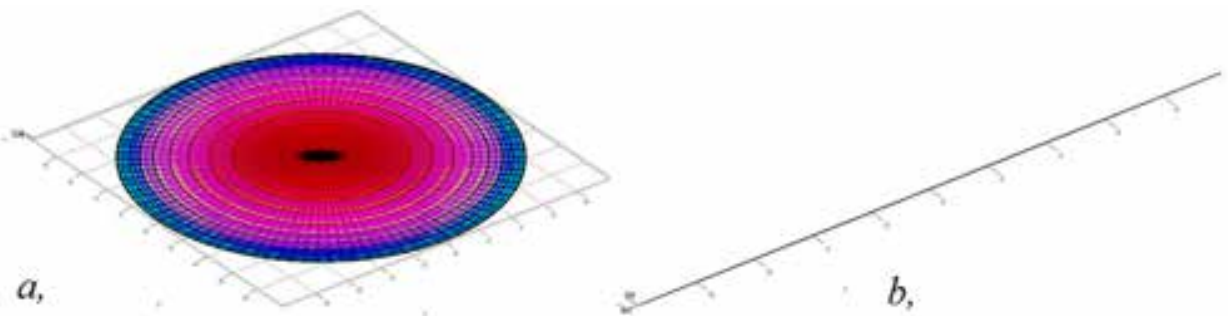

17. ábra. Érme- $(a)$ és tű alakú $(b)$ inhomogenitás 
Az inhomogenitás alakjának hatását vizsgálva a következő kiindulási adatokat alkalmaztuk:

$a_{1}=10 \mathrm{~mm} ; a_{2}=9,9 \mathrm{~mm} ; a_{3}=9,8 \mathrm{~mm}$.

$c_{0}=0,4 ; c_{1}=0,6$;

$E_{0}=20 \mathrm{GPa} ; E_{1}=30 \mathrm{GPa}$;

$\nu_{0}=0,15 ; \nu_{1}=0,20$.

A kezdeti alakhoz tartozó $a_{1}$ értéket rögzítve, az $a_{2}$ és $a_{3}$ értékeket változtattuk a paraméteres vizsgálat során.

Az inhomogenitás alakját változtatva megfigyelhető, hogy minél torzultabb az adalékanyag a gömbhöz képest, annál merevebb lesz az elkészült betonkeverék. Természetesen beton esetében a cementkő és a folyami kavics adalékanyagok anyagállandóinak értéke között nincs nagy (nagyságrendnyi) különbség, emiatt az effektív jellemzők sem különböznek nagymértékben, azonban a tendencia mindenképpen ebbe az irányba mutat.

3. táblázat. Az inhomogenitás alakjának hatása a heterogén anyag átlagos rugalmassági modulusánk értékére

\section{Inhomogenitás alakjának hatása}

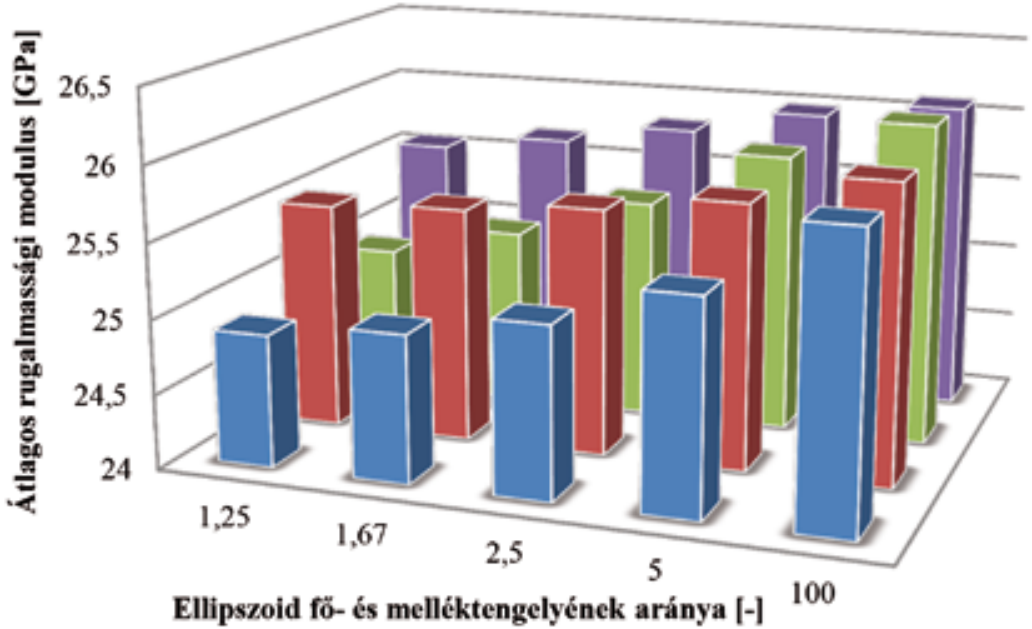

\begin{tabular}{|l|c|c|c|c|c|}
\cline { 2 - 6 } \multicolumn{1}{c|}{} & 1,25 & 1,67 & 2,5 & 5 & 100 \\
\hline " Eshelby (o) & 24,89 & 24,99 & 25,15 & 25,42 & 25,92 \\
\hline - Mori - Tanaka (o) & 25,52 & 25,57 & 25,65 & 25,77 & 25,98 \\
\hline " Eshelby (p) & 24,98 & 25,19 & 25,48 & 25,87 & 26,15 \\
\hline " Mori - Tanaka (p) & 25,56 & 25,67 & 25,81 & 25,98 & 26,09 \\
\hline
\end{tabular}




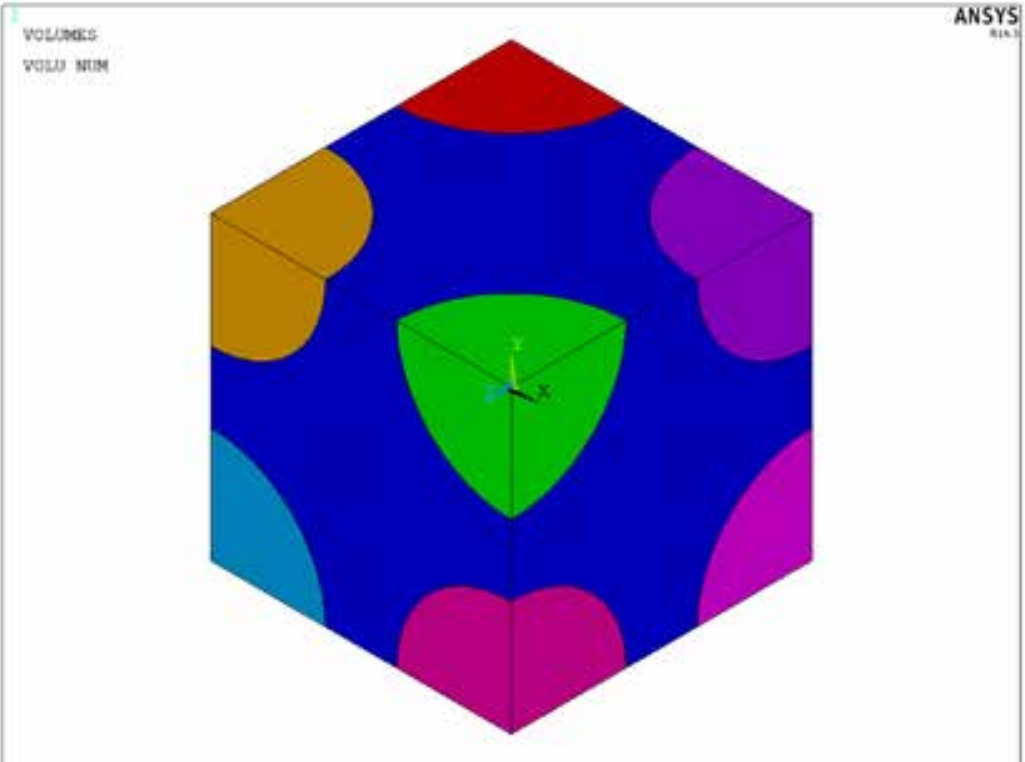

18. ábra. A cementkő és a beleágyazott kavicsok geometriai modellje

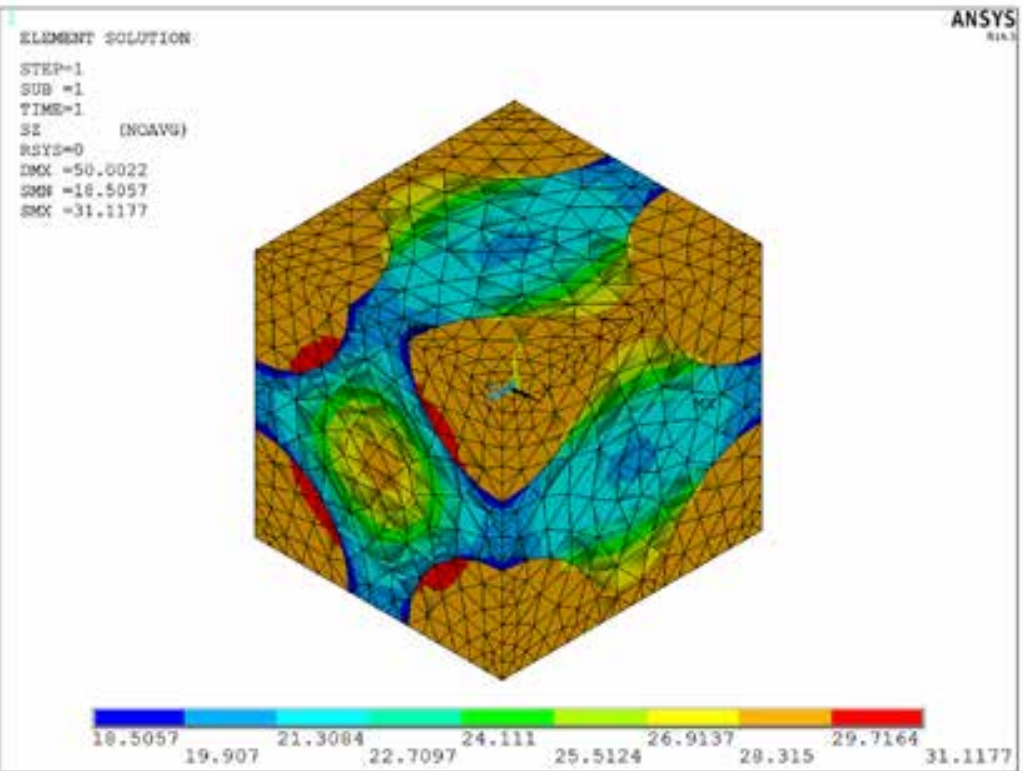

19. ábra. A numerikus homogenizáció során tapasztalt jellegzetes feszültségeloszlás 
Az analitikus homogenizációt összevetettük numerikus számítások eredményeivel is, ahol a reprezentatív térfogatelemre egységnyi alakváltozást előírva, és az egyes elemekben keletkező feszültségeket átlagolva kaphatjuk meg az átlagos anyagi merevségi mátrixot, melyből kiszámítható az átlagos rugalmassági modulus és a Poisson-tényező (Barbero 2014).

A végeselemes számításokat Ansys ${ }^{\mathrm{TM}}$ Mechanical APDL programban végeztük el, az egyes adalékanyagokat ellipszoidként modelleztük (18. ábra). A képen a sarkokban és a blokk közepén helyezkednek el az adalékanyag-szemcsék, és a köztük lévő teret tölti ki a cementkő.

Az egységnyi nyúlást irányonként előírva, majd az egyes teheresetekhez tartozó feszültségmezőket átlagolva az anyagi merevségi mátrix elemeit oszloponként meghatároztuk. A feszültségmezőn jól látható, hogy az egyes szemcsék között hogyan adódnak át a terhek, ezeken a szakaszokon az egyébként kisebb rugalmassági modulusszal rendelkező cementkő is merevebben viselkedik (19. ábra).

Egy táblázatba összefoglalva az eredményeket, összehasonlíthatóak az analitikus, valamint a numerikus becslések:

4. táblázat. A két-, három- és négyfázisú modellek analitikus, illetve numerikus homogenizáció során nyert eredményei a fázisok térfogatarányának függvényében

\begin{tabular}{|c|c|c|c|c|c|c|c|c|}
\hline \multirow{2}{*}{$\mathrm{c}_{0}$} & \multirow{2}{*}{$\mathrm{c}_{1}$} & \multirow{2}{*}{$\mathrm{c}_{2}$} & \multirow{2}{*}{$\mathrm{c}_{3}$} & \multicolumn{5}{|c|}{ Átlagos rugalmassági modulus (GPa) } \\
\cline { 5 - 9 } & & & & VEM (1) & VEM (2) & Voigt & Eshelby & Mori-Tanaka \\
\hline 0,4 & 0,6 & 0 & 0 & 23,29 & 23,69 & 26,04 & 25,19 & 25,67 \\
\hline 0,4 & 0,55 & 0,05 & 0 & 21,96 & 21,96 & 24,53 & 22,84 & 22,94 \\
\hline 0,4 & 0,52 & 0,05 & 0,03 & 23,94 & 24,09 & 29,86 & 28,78 & 29,03 \\
\hline
\end{tabular}

Az átlagos rugalmassági modulusok értékeinél a 4. táblázat első sora a kétfázisú, a második és harmadik a három-, illetve négyfázisú modellek eredményeit tartalmazza.

Az adalékanyag mérete:

$a_{1}=10 \mathrm{~mm} ; a_{2}=6,1 \mathrm{~mm} ; a_{3}=6 \mathrm{~mm}$;

a három- és négyfázisú modell esetén a légpórusok mérete:

$a_{1}=0,5 \mathrm{~mm} ; a_{2}=0,49 \mathrm{~mm} ; a_{3}=0,48 \mathrm{~mm}$;

a négyfázisú modell esetén az acélszálak mérete:

$a_{1}=1 \mathrm{~mm} ; a_{2}=0,002 \mathrm{~mm} ; a_{3}=0,001 \mathrm{~mm}$;

a cement, az adalékanyag és az acélszál anyagjellemzői:

$E_{0}=20 \mathrm{GPa} ; E_{1}=30 \mathrm{GPa} ; E_{3}=200 \mathrm{GPa}$;

$\nu_{0}=0,15 ; \nu_{1}=0,20 ; \nu_{3}=0,3$. 
Az első két oszlopban a numerikus eljárások két különböző irányban (,1” és „,2”) számított rugalmassági modulusainak értékei láthatók. Az eredmények minden esetben a Voigt-féle felső határ alá esnek, és képesek figyelembe venni a mikropórusok merevséget csökkentő, valamint az acélszálak merevséget növelő hatását.

\section{ÖSSZEFOGLALÁS}

A numerikus módszerek nagy előnye, hogy jól modellezik az egyes szemcsék közti teherátadódást, tehát az egyes fázisok eloszlásának és orientációjának hatását, valamint azt, amit az analitikus képletek egyáltalán nem tudnak figyelembe venni, nevezetesen az egyes inhomogenitások méretének szerepét. Megjegyezzük, hogy a geometriai modell felépítése rendkívül időigényes, és testelemek használatával már egy egyszerű számítás is megnöveli a homogenizáció időszükségletét. Jelen feladat egy személyi számítógépen futtatva az analitikus eljárások esetén körülbelül 30 másodpercet, a numerikus számítás esetén körülbelül 3 órát vesz igénybe (a modellek felépítéséhez szükséges időtől eltekintve). A numerikus számítás időigényes volta ellenére könnyedén beilleszthető bármely szoftver megoldó algoritmusába, ezáltal összecsatolva egy általános mérnöki probléma és a numerikus homogenizáció megoldását.

Az analitikus eljárások nagyon gyorsak, kevés kiindulási adatra van szükség, és tulajdonképpen már néhány egyszerü számítás segítségével meghatározható a kívánt effektív anyagi paraméter értéke. Az analitikus homogenizáció hátránya, hogy sok feltevést és egyszerüsítést alkalmaz, ezért minden egyes módszerhez gondosan meg

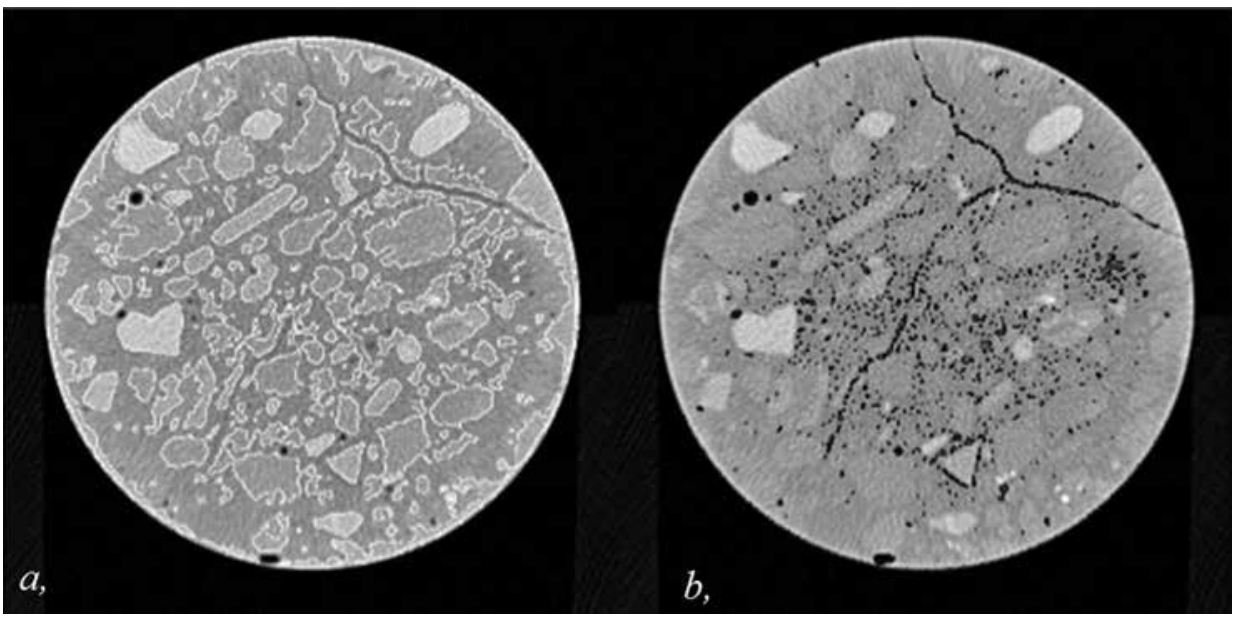

20. ábra. Elkülönített kavics $(a)$ és légpórus $(b)$ fázisok egy beton próbatestről készült CT felvételen (Lublóy et al. 2014) 
kell vizsgálni az alkalmazhatósági feltételeket. Az Eshelby-tenzor számításánál használt elliptikus integrálok szintén közelítő megoldást nyújtanak, ezért vitatható az egyes analitikus eljárás pontossága. Érdemes lenne összevetni az egyes módszerek által nyújtott eredményeket olyan heterogén anyag esetén is, ahol a különböző fázisok anyagtulajdonságai nagymértékben eltérnek egymástól.

Egy egyszerü alkalmazásként például egy betongyárban a betonkeverék minőségét számító program tudná alkalmazni az analitikus homogenizációs technikákat. A beérkező különböző minőségü és alakú adalékanyagból készített betonkeverék átlagos rugalmassági modulusa és Poisson-tényezője könnyedén becsülhető az egyes fázisok térfogataránya és rugalmassági modulusa, valamint Poisson-tényezöje alapján. Ha az adalékanyag szemcséinek nagyságát is ismerjük, még jobb közelítés adható a betonkeverék átlagos anyagi paramétereire.

\section{TOVÁBBI ALKALMAZÁSOK BEMUTATÁSA}

A számítógépes homogenizáció próbatestekről vagy kész szerkezetekről készült ipari CT felvételek feldolgozása során is használható. Ennek nagy előnye, hogy a heterogén anyag belsejébe teljesen „belelátunk” anélkül, hogy a szerkezetet roncsolásos vizsgálatnak vetnénk alá (20. ábra). Ezáltal az anyagban a valós heterogenitás-eloszlást tudjuk modellezni, és a kapott eredmények is a konkrét próbatestre vonatkoznak.

A CT felvételek alapján történő anyagmodellezés rendkívül hasznos lehet károsodott szerkezetek vizsgálatánál (Lublóy et al. 2014), ugyanis egy mobil-CT használatával roncsolásmentesen tudnánk felvételeket nyerni a károsodott szerkezet szemmel nem látható részeiről, és így végeselemes számítások segítségével ellenőrizhető a

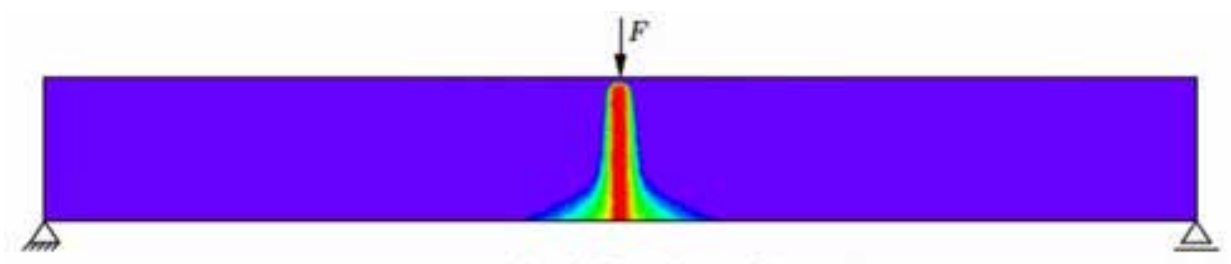

$a$, makrosakopikas tonkcremenctel

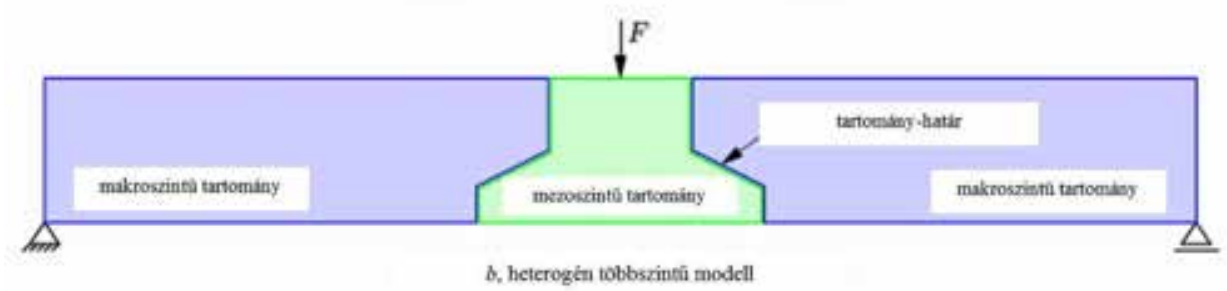

21. ábra. Többszintủ modellezés alkalmazása (Eckardt 2009) 
szerkezet aktuális teherbírása, valamint számítható lenne egy várható élettartam is az ismert terhek esetén.

Különleges homogenizációt használunk a bevezetöben már említett többszintü modellezés esetében is. Ennek lényege, hogy az egyébként kontinuumként modellezett szerkezetet a tönkremenetele szempontjából kritikusnak vélt helyeken egy „mélyebb" szintet tartalmazó anyagmodellel váltjuk ki. A makroszintü probléma deformációit a mikroszintủ reprezentatív térfogatelem peremeire transzformálva megoldunk az „alacsonyabb” szinten egy klasszikus peremérték-feladatot, és az itt kapott feszültségeket a numerikus homogenizáció segítségével átvisszük a szerkezet szintjére (Geers et al. 2011).

\section{IRODALOMJEGYZÉK}

Barbero, E. J. (2014). Finite Element Analysis of Composite Materials Using ANSYS. CRC Press.

Eckardt, S. (2009). Adaptive heterogeneous multiscale models for the nonlinear simulation of concrete. Weimar, Bauhaus-Universitat Weimar.

Eshelby, J. D. (1957). The determination of the elastic field of an ellipsoidal inclusion, and related problems. Proc. Roy. Soc., A241, 376-396.

Gábor, E. (2014). Mechanical Modelling of the Mesostructure of Heterogeneous Materials. Budapest, M.Sc. thesis.

Geers, M. - Kouznetsova, V. - Brekelmans, M. (2011). Scale transitions in solid mechanics based on computational homogenization. CISM Advanced School. Udine.

Hashin, Z. (1988). The differential scheme and its applications to cracked materials. J. Mech. Phys. Solids 36, 719-734.

Hashin, Z. - Shtrikman, S. (1961). Note on a variational approach to the theory of composite elastic materials. J. Franklin Inst. 271, 336-341.

Hashin, Z. - Shtrikman, S. (1963). A variational approach to the theory of the elastic behaviour of multiphase materials. J. Mech. Phys. Solids 11, 127-140.

Hill, R. (1963). Elastic properties of reinforced solids: some theoretical principles. J. Mech. Phys. of Solids 11, 357-372.

Hill, R. (1965). A self-consistent mechanics of composite materials. J. Mech. Phys. Solids 13, 213-222.

Lublóy, É. - Balázs, G. L. - Kapitány, K. - Barsi, Á. - Földes, T. (2014). Analysis of fire damaged reinforced concrete structures by computed tomography (CT). Concrete Structures 16 (4) 86-90.

Meng, C. - Heltsley, W. - Pollard, D. D. (2012). Evaluation of the Eshelby solution for the ellipsoidal inclusion and heterogeneity. Comput. Geosci. 40, 40-48.

Meng, C. - Pollard, D. D. (2014). Eshelby's solution for ellipsoidal inhomogeneous inclusions with applications to compaction bands. Journal of Structural Geology 67, 1-19.

Mori, T. - Tanaka, K. (1973). Average stress in matrix and average elastic energy of materials with misfitting inclusions. Acta Metall. 21, 571-574.

Mura, T. (1987). Micromechanics of defects in solids. Dordrecht, Martinus Nijhoff Publishers.

Qu, J. - Cherkaoui, M. (2006). Fundamentals of Micromechanics of Solids. John Wiley \& Sons, Inc.

Willis, J. R. (1977). Bounds and self-consistent estimates for the overall properties of anisotropic composites. J. Mech. Phys. Solids 25, 185-202.

Willis, J. R. (1981). Variational and related methods for the overall properties of composites. Adv. Appl. Mech. 21, 1-78. 


\title{
MECHANICAL MODELLING OF THE MESOSTRUCTURE OF HETEROGENEOUS MATERIALS
}

\begin{abstract}
Summary
The importance of studying the mesostructure of heterogeneous materials appears in both multiscale modelling and materials technology. Based on the theories of micromechanics we show as an illustrative example the analytical - including the Eshelby tensor - and the finite element computation of the stress field in a material containing a single inhomogeneity. In the second part of the paper we introduce the homogenization techniques connecting the different scales in material modelling. We demonstrate this averaging method in case of the meso- and macrolevel modelling of concrete. After comparing the results of analytical and numerical homogenization, we outline some other possible fields of application.
\end{abstract}

Keywords: heterogeneous material, mesoscale, Eshelby, Mori-Tanaka, homogenization, concrete 